\title{
Consent Cannot Control: Peretz v. United States and Federal Magistrate Judge Jurisdiction in Felony Cases
}

\author{
Kyle D. Fields*
}

"A magistrate judge may be assigned such additional duties as are not inconsistent with the Constitution and the laws of the United States." 28 U.S.C. $\S 636(b)(3)$.

"[W]e must give content to the additional duties clause by looking to Congress' intention that magistrates be delegated administrative and other quasi-judicial tasks in order to free Article III judges to conduct trials, most particularly felony trials." Peretz v. United States, 501 U.S. 923, 948 (1991) (Marshall, J., dissenting) (emphasis in original).

In Peretz v. United States, ${ }^{1}$ a bare majority of the Supreme Court held that the "additional duties" clause of the Federal Magistrates Act permits a magistrate judge ${ }^{2}$ - with a defendant's consent - to preside over voir dire ${ }^{3}$ at a felony trial. The majority also did not perceive any constitutional danger arising from the exercise of the "judicial Power of the United States" by an Article I officer. ${ }^{4}$ At first glance, the result appears to be a common-sense victory for efficiency, and the vast majority of citations to Peretz do not involve reflection upon proper statutory interpretation, structural analysis, or the significance of certain judicial functions. Rather, Peretz has been cited ad nauseum for the

* Kyle Fields has been an attorney in the Office of Chief Counsel at the Federal Railroad Administration since 2016. He earned his J.D. from Indiana University Maurer School of Law in 2013. Kyle thanks Julia Rickert, Jeremy Votaw, Elliott Gillooly, Sam Gilbert, and his wife LiMin Hang Fields for insightful edits and discussions. The views expressed in this article do not necessarily represent the views of the Federal Railroad Administration or the United States.

1. 501 U.S. 923 (1991)

2. The shorter title "magistrate" was used from enactment of the Federal Magistrates Act of 1968 until December 1990. Except for direct quotations, this article uses the title "magistrate judge" throughout.

3. Throughout this article, references to "voir dire" should be understood to include both questioning of the venire and actual juror selection (i.e., use of peremptory and cause challenges). It does not necessarily extend to formal empaneling of the jury (i.e., the formality of swearing-in the selected jurors); the concern is the substantive questioning and selection of the potential jurors.

4. U.S. CONST. art. III, $\S 1$. 
general propositions that "[t]he most basic rights of criminal defendants are... subject to waiver," and, "the role of the magistrate in today's federal judicial system is nothing less than indispensable."

Closer examination of Peretz and its context reveals important underlying issues. This article does not suggest that Article I magistrate judges are any less thoughtful than their life-tenured Article III colleagues. Rather, the focus is on the statutory, constitutional, and practical distinctions between Article I and Article III judges. As a constitutional matter, magistrate judges are not members of the federal judiciary, ${ }^{6}$ however "indispensable" they may have become. And to allow them to conduct all duties of district judges threatens (eventually) to make life-tenured judges entirely dispensable, given the difficulty of filling judicial vacancies ${ }^{7}$ and the empirical data that magistrate judges are performing more and more work every year. ${ }^{8}$ The last quartercentury has seen an increase in federal court filings but no corresponding increase in Article III judgeships. ${ }^{9}$ The Peretz majority invited a slow but inexorable shift to Article I officers as the solution by failing to (1) adhere to the limits placed on magistrate judge jurisdiction by Congress, (2) appreciate the danger of allowing the judiciary to delegate away its core power, or (3) recognize the inherent significance of felony voir dire. ${ }^{10}$ In so doing, the majority's rationale departed from other Supreme Court decisions both before and since. ${ }^{11}$

5. Peretz, 501 U.S. at 936 (collecting cases); id. at 928 (Virgin Islands v. Williams, 892 F.2d 305, 308 (3d Cir. 1989)). See also, e.g., Kelly Holt, Comment, Congressional Guidance on the Scope of Magistrate Judges' Duties, 84 U. CHI. L. REV. 909, 909 (2017) (opening with the statement that "[m]agistrate judges are "nothing less than indispensable' to the modern judicial system," before examining the current circuit split regarding magistrate judge jurisdiction over felony guilty pleas).

6. Empirical research of federal civil matters demonstrates that magistrate judges have different propensities toward certain outcomes than district judges. See Christina Boyd, The Comparative Outputs of Magistrate Judges, 16 NEV. L.J. 949, 981-82 (2016).

7. See Judicial Vacancies, UNITED STATES COURTS, http://www.uscourts.gov/judgesjudgeships/judicial-vacancies [https://perma.cc/Y6RF-UEVA] (last visited Oct. 6, 2018).

8. Douglas Lee \& Thomas Davis, "Nothing Less Than Indispensable": The Expansion of Federal Magistrate Judge Authority and Utilization in the Past Quarter Century, 16 NEV. L.J. 845, 935-36 (2016).

9. The Judicial Conference of the United States consistently requests legislation to create new Article III judgeships, as the last comprehensive judgeship legislation was passed in 1990. See, e.g., Judicial Conference Asks Congress to Create New Judgeships, UNITED STATES COURTs (March 14, 2017), http://www.uscourts.gov/news/2017/03/14/judicial-conference-asks-congress-create-newjudgeships [https://perma.cc/P6B3-PNNP].

10. See generally, Daniel Hinde, Consensual Sentencing in Magistrate Court, 75 TEX. L. REV. 1161, 1171-73 (1997) (explaining that Peretz "approve[d] magistrate judge duties and judicial processes developed by the courts themselves," beyond the delegation from Congress).

11. This article is not concerned with the conclusion that a defendant's individual right to an Article III adjudicator is waivable, for that result is consistent with many other decisions. See, e.g., Commodities Future Trading Comm'n v. Schor, 478 U.S. 833, 851-57 (1986). 
For example, the Peretz majority did not repudiate the persuasive statutory analysis from Gomez v. United States just two years earlier, which concluded that Congress did not intend felony voir dire to be an "additional duty" for magistrate judges. ${ }^{12}$ Rather, it fashioned a consent requirement for certain significant additional duties - such as felony voir dire-when conducted by magistrate judges, to be grafted onto both statutory analysis and constitutional analysis. This result runs contrary to Congress's express intention that delegation of some matters to magistrate judges would allow time for district judges to perform felony adjudications - which is evident, even for pure textualists, in the explicit provisions for magistrate judges to conduct civil trials ${ }^{13}$ and misdemeanor trials ${ }^{14}$ with litigant consent, with no mention of similar authority for felony trials. Further, this approach is inconsistent with the subsequent majority opinion in Nguyen $v$. United States, which held that an Article IV judge could not sit by designation on a court of appeals panel where Congress has not empowered him to do so (even with litigant consent). "Congress's decision to preserve the Article III character of the courts of appeals is more than a trivial concern ... and is entitled to respect." 15

As this article explains more fully, the Peretz majority also departed from other Article III structural cases, especially by focusing so heavily on litigant consent ${ }^{16}$ and conflating civil matters with felony criminal matters. ${ }^{17}$ By making litigant consent dispositive in Peretz (as the only factor distinguishing Gomez), the Supreme Court invited dangerous dicta in Wellness International Network, Ltd. v. Sharif, where another narrow majority suggested that litigant consent can cure even Article III structural violations. ${ }^{18}$ Still, the holding in Sharif does not portend the end of Article III adjudicators, for bankruptcy judges address only civil matters. Thus, the state-law claims at issue in Sharif might have been

2. See 501 U.S. at 932-33; Gomez v. United States, 490 U.S. 858, 872 (1989).

13. 28 U.S.C. $\S 636(\mathrm{c})(1)(2012)$

14. 18 U.S.C. $\$ 3401(2012)$.

15. 539 U.S. 69, 79-80 (2003) (citation omitted).

16. Compare Peretz, 501 U.S. at 936, with Schor, 478 U.S. at 851-57.

17. Compare Peretz, 501 U.S. at 936, with Wellness Int'1 Network, Ltd. v. Sharif, 135 S. Ct. 1932, 1945 (2015) ("[B]ankruptcy courts possess no free-floating authority to decide claims traditionally heard by Article III courts.").

18. See Sharif, 135 S. Ct. at 1943 ("But allowing Article I adjudicators to decide claims submitted to them by consent does not offend the separation of powers so long as Article III courts retain supervisory authority over the process."); Id. at 1950 (Roberts, C.J., dissenting) ("Despite our precedent directing that 'parties cannot by consent cure' an Article III violation implicating the structural separation of powers..., the majority authorizes litigants to do just that.") (citation omitted). 
heard (in the alternative) by an elected state judge with substantially fewer protections of independence than even a bankruptcy judge, let alone a life-tenured district judge. ${ }^{19}$ The holding in Peretz does represent that danger, because it addresses federal felony proceedings, where the most significant elements could only be adjudicated in federal court and should be reserved for Article III judges. ${ }^{20}$ The concern is not the fairness of any one particular trial, ${ }^{21}$ but the need to draw certain lines in all trials to protect some inviolable role for life-tenured, Senateconfirmed district judges.

One might inquire: If Peretz is so inconsistent with other Supreme Court opinions, and the danger to judicial independence so clear, why does it deserve re-examination? The main concern is continued reliance on Peretz as a resource for both statutory and constitutional questions regarding magistrate judges' powers. In the wake of the bankruptcy decisions Stern v. Marshall and Sharif, ${ }^{22}$ several commentators have explored whether magistrate judges have the power to preside over certain significant felony proceedings, such as guilty plea colloquies and collateral attacks, and none have fully recognized the extent to which the flaws in Peretz demand careful consideration of other relevant precedent. $^{23}$ Federal courts themselves are also a concern, as multiple circuit courts of appeals have relied upon Peretz to broaden magistrate judges' authority ever further, extending the contours of the Federal Magistrates Act and Article III itself. ${ }^{24}$ Instead, proper analysis of magistrate judges' authority must consider the many cases running contrary to the almost-purely pragmatic analysis of Peretz that elevates

19. See F. Andrew Hessick, Consent to Adjudication Outside the Article III Courts, 71 VAND. L. REV. 715, 741-45 (2018).

20. How can a litigant's consent imbue a federal tribunal with authority it otherwise lacks? See Nguyen v. United States, 539 U.S. 69, 73-74 (2003). And how voluntary can the judiciary's delegation of its tasks be, and a defendant's acquiescence to that delegation, when faced with certain and substantial delay in the alternative? See Peretz, 501 U.S. at 948 (Marshall, J., dissenting).

21. See generally Weaver v. Massachusetts, 137 S. Ct. 1899, 1910 (2017).

22. Stern v. Marshall, 564 U.S. 462 (2011); Sharif, 135 S. Ct. 1932.

23. See, e.g., Grant Ford, Note, Bringing United States v. Harden to Its Conclusion: The Seventh Circuit's Reluctance to Act on the Flawed Decision's Consequences, 61 ST. LouIS L.J. 323 (2017); Steven Maguire, Too Much of a Stretch: Why Acceptance of Felony Guilty Pleas by Federal Magistrates Defies the Intent of Congress and Erodes the Rights of the Accused Regardless of Consent, 9 DreXel L. ReV. ONLINE 31 (2017); Holt, supra note 5; Andrew Chesley, Note, The Scope of United States Magistrate Judge Authority After Stern v. Marshall, 116 ColuM. L. REv. 757 (2016); Tomi Mendel, Note, Efficiency Run Amok: Challenging the Authority of Magistrate Judges to Hear and Accept Felony Guilty Pleas, 68 VAND. L. REV. 1795 (2015).

24. See, e.g., United States v. Benton, 523 F.3d 424 (4th Cir. 2008). But see United States v. Harden, 758 F.3d 886 (7th Cir. 2014); United States v. Brown, 748 F.3d 1045 (11th Cir. 2014). 
litigant consent above all other concerns. ${ }^{25}$

Three paths could counter the danger of Peretz. First, district courts should decline the invitation to alienate power over felony voir direwhich is unreviewable as a practical matter ${ }^{26}$ - and use local rules to retain exclusive jurisdiction over that duty at the threshold of felony trial itself. Second, courts and commentators should be careful to place Peretz in the proper context (i.e., should recognize its inconsistencies with decisions such as Wingo v. Wedding, United States v. Raddatz, Northern Pipeline Construction Co. v. Marathon Pipe Line Co., Schor, Gomez, Nguyen, and Stern $)^{27}$ to avoid, through a narrow focus on one case, removing statutory and constitutional constraints on magistrate judges' authority. Third, to reinforce the first and second solutions when the opportunity arises, the Supreme Court should overrule Peretz. ${ }^{28}$ This would preserve the entire scope of felony trial for Article III judges alone without upsetting Article III jurisprudence generally (for example, the line drawn in bankruptcy cases in Stern and Sharif).

This article explores the history of Federal Magistrates Act jurisprudence to show that the Peretz majority was, in many ways, an aberration from the outset, as reflected in the cogent dissents of Justices Thurgood Marshall and Antonin Scalia. It proceeds to consider subsequent decisions and to establish that even the flexible, multifactor structural analysis that prevails today should not allow anyone except a life-tenured Article III judge to preside at voir dire. Finally, it examines the dangers as courts and commentators continue to embrace Peretz without considering its context and consequences.

25. For a comprehensive analysis of the dangers of jurisdiction conferred by consent, see generally Hessick, supra note 19.

26. See Peretz v. United States, 501 U.S. 923, 951 (1991) (Marshall, J., dissenting); Gomez v. United States, 490 U.S. 858, 874 (1989).

27. One must note that Justice Stevens authored three critical cases on these issues: Gomez, Peretz, and Nguyen (in that order). This puzzle does not permit easy resolution, as Peretz is simply inconsistent with the prior decision (Gomez) and subsequent decision (Nguyen). At the very least, one must thoroughly address all three opinions to understand that litigant consent and efficiency concerns cannot override the limits placed by Congress and the constitution. To read Peretz alone is to miss critical competing concerns articulated in Gomez, Nguyen, and other opinions.

28. Congress could clarify that Gomez rather than Peretz provides the correct reading of the Additional Duties Clause and could provide additional Article III judgeships, but this notion is almost fanciful. The judiciary itself has invited the consequences of Peretz, and, unless and until the legal community embraces a solution, Peretz encourages erosion of powers that ought to be reserved to district judges. See generally Kimberly Anne Huffman, Peretz v. United States: Magistrates Perform Felony Voir Dire, 70 N.C. L. REv. 1334, 1361 (1992). 


\section{The RoAd to PERETZ V. United StATES}

In Peretz, the Supreme Court faced the intersection of several questions regarding felony voir dire-its importance in the overall felony trial process, its eligibility as an "additional duty" under $\S 636$, and the extent of district judge supervision required by Article III. To properly examine Peretz, it is necessary to consider the framework that federal courts developed to resolve similar questions prior to the decision. That framework reveals weaknesses in Peretz that should have been evident at the time it was decided, and that remain even a quarter-century later.

\section{A. The Significance of Voir Dire}

In practice, voir dire is not just important-it is vital. For adherents to the view that voir dire is truly a preliminary matter of no particular significance, the outcome in Peretz might appear straightforward, and this article trivial. ${ }^{29}$ This conclusion assumes that voir dire is no more than a preliminary matter on the fringe of a felony trial and overlooks the importance many judges, attorneys, and commentators accord to the identity of jurors. $^{30}$

To minimize voir dire is to ignore the reality that jurors' identities impact final verdicts. ${ }^{31}$ While jurors and litigants may have a common interest in fairly-balanced venires generally, those interests diverge in any individual case as the litigants seek a favorable outcome by all available means. $^{32}$ The presiding judge must balance these competing interests, and each act - from ruling on a request to strike for cause to merely setting the time for juror questioning - might affect the outcome of the case. By the time the presentation of arguments and evidence commences, the presiding judge has already played a critical role in

29. Even before Peretz was decided, the en banc Fifth Circuit offered a retort to this point of view: "With respect, we see voir dire in a different light - of greater importance. The trial lawyer knows that who decides the truth from the evidence may be as important as the evidence." United States v. Ford, 824 F.2d 1430, 1437 (5th Cir. 1987).

30. See id. at 1438. By express authority, magistrate judges may preside over civil trials, 28 U.S.C. § 636, and misdemeanor trials, 18 U.S.C. § 3401, but only with consent. Unless and until Peretz is extended further, as this article opposes, felony trial proceedings (with the unfortunate exception of felony voir dire) are reserved for district judges.

31. See, e.g., Edward Adams \& Christian Lane, Constructing a Jury That Is Both Impartial and Representative: Utilizing Cumulative Voting in Jury Selection, 73 N.Y.U. L. REV. 703, 704-08 (1998) (discussing significance of racial diversity among jurors); see also Fred Hagans \& William Hagans, Jury Selection in Personal Injury Cases, 77 THE ADVOC. (TEXAS) 44, 44 (2016) (recounting example where three different focus groups found 10\% liability, 30\% liability, and $100 \%$ liability).

32. See Jury Selection and Composition, 110 HARV. L. REV. 1443, 1449-50 (1997). 
ensuring the integrity of the jury.

The importance of voir dire has long been recognized. As early as 1880 , the Supreme Court explained "the constitution of juries is a very essential part of the protection that [trial by jury] is intended to secure." Just over a decade later, the Court established that a felony trial starts from the time "the work of [e]mpaneling the jury" begins (i.e., the beginning of voir dire). ${ }^{34}$ The questioning and selection of jurors is the threshold that leads to the "attachment of jeopardy." 35 Finally, as Batson v. Kentucky instructs, voir dire presents an unusual context where each participant-whether a defendant or a prospective juror-has a constitutional right to be protected from "the arbitrary exercise of power by prosecutor or judge." $"$ In short, the Supreme Court has recognized voir dire as part of trial for over a century, and, just five years before Peretz was decided, the Supreme Court championed the importance of voir dire for both defendants and jurors themselves. Any analysis regarding a presiding judicial officer's authority should reflect this context.

The Supreme Court recognized both the practical and legal significance of voir dire in its decisions regarding racial and gender bias from peremptory challenges. ${ }^{37}$ Voir dire provides the "means of discovering actual or implied bias" for the intelligent use of peremptory challenges, and the presiding officer must facilitate the process while identifying potential impermissible bias. ${ }^{38}$ By the time of J.E.B., Justice O'Connor freely acknowledged that "constitutionalizing" voir dire and jury selection had moved the process from "a sideshow" to "part of the main event" (i.e., part of trial). ${ }^{39}$ The Batson majority also addressed the argument that constitutional scrutiny of peremptory challenges would create undue burden on trial courts, noting that state courts prohibiting race-based peremptory challenges had "not experienced serious

33. Strauder v. West Virginia, 100 U.S. 303, 308 (1880). Strauder was a groundbreaking Equal Protection Clause case, and it proved to be an essential foundation for twentieth-century Supreme Court decisions regarding racial discrimination in the criminal process. See Michael J. Klarman, The Racial Origins of Modern Criminal Procedure, 99 MicH. L. REV. 48, 65 (2000).

34. Lewis v. United States, 146 U.S. 370, 374 (1892).

35. See, e.g., Serfass v. United States, 420 U.S. 377, 388 (1975); see also Ford, 824 F.2d at 1437 ("That double jeopardy does not attach until a jury is sworn does not suggest that the selection of the petit jury is preliminary.").

36. Batson v. Kentucky, 476 U.S. 79, 86-87 (1986).

37. Id. (prohibiting race-based peremptory challenges); J.E.B. v. Alabama ex rel. T.B., 511 U.S. 127, 146 (1994) (prohibiting gender-based peremptory challenges).

38. J.E.B., 511 U.S. at $143-44$

39. See id. at 147 (O’Connor, J., concurring); see also Lewis, 146 U.S. at 374. 
administrative burdens." 40 Given that the Supreme Court does not view judicial supervision of voir dire as a serious administrative burden, it is difficult to understand why district courts need the power to assign that role to magistrate judges. ${ }^{41}$

Any effort to preserve the exclusive role of Article III judges at felony trial should extend to felony voir dire. Indeed, equating felony voir dire with civil and misdemeanor trials - as the Peretz majority didthreatens to erase the distinction between felony trials and other adjudications entirely.

\section{B. Determining the Scope of Magistrate Judges' "Additional Duties"}

The Magistrates Act of 1968 replaced United States Commissioners with expanded roles for new United States Magistrates in an effort to ease caseload burdens for federal district judges. ${ }^{42}$ From the beginning, federal magistrates (since 1990, "magistrate judges") could perform "such additional duties as are not inconsistent with the Constitution and the laws of the United States."43 The explicitly-listed duties included "preliminary review of applications for post-trial relief made by individuals convicted of criminal offenses, and submission of a report and recommendations to facilitate the decision of the district judge having jurisdiction over the case as to whether there should be a hearing." 44 In Wingo v. Wedding, the Supreme Court considered whether a magistrate judge could conduct the habeas hearing itself (on a petition under 28 U.S.C. $\S 2241$ regarding a state conviction ${ }^{45}$ ), over the petitioner's objection and subject to de novo review of the recording by a district judge. ${ }^{46}$

The Wingo majority, authored by Justice Brennan, looked to both the text and legislative history of the Additional Duties Clause in

\footnotetext{
40. Batson, 476 U.S. at 99.

41. Any attempt to distinguish felony voir dire from felony trial also results in a puzzling distinction in light of the Fifth Amendment. Each defendant may be placed in jeopardy only once, and that right attaches upon empaneling of the jury, which is a hollow formality after voir dire has been conducted. See Lewis, 146 U.S. at 374; Serfass, 420 U.S. at 388; U.S. CONST. amend. V.

42. Wingo v. Wedding, 418 U.S. 461, 462-63 (1974).

43. Judicial Improvements Act of 1990, Pub. L. No. 101-650, § 321, 104 Stat. 5089, 5117 (1990).

44. Id.; see also Wingo, 418 U.S. at 471 (explaining the duties listed in the Judicial Improvement Act).

45. Whether a federal magistrate judge may preside over a hearing on a 28 U.S.C. $\S 2255$ petition - and potentially invalidate a decision by a federal district judge - remains an open question. See, e.g., Brown v. United States, 748 F.3d 1045, 1047 (11th Cir. 2014).

46. 418 U.S. at $465-66$.
} 
$\S 636(\mathrm{~b})(3) .^{47}$ The majority examined other portions of the statute that explicitly allowed magistrate judges to preside over hearings or trials and contrasted the limiting language regarding hearings on petitions for habeas corpus, reasoning that the absence of similar language for posttrial hearings was an implicit prohibition. ${ }^{48}$ The legislative history further clarified that the addition of the limiting language in $\S 636(\mathrm{~b})(3)$ had been included in response to an objection from the Judicial Conference of the United States to the idea of magistrates conducting post-trial evidentiary hearings. ${ }^{49}$ Thus, it was error for a magistrate to preside over a habeas hearing, and the majority concluded that de novo review by the district judge could not cure the error because even the availability of a recording of oral testimony was not "the equivalent of the judge's own exercise of the function of the trier of the facts." majority squarely rejected the notion that the Additional Duties Clause should be read broadly to the limits of Article III, despite Chief Justice Burger's position in his Wingo dissent. ${ }^{51}$

In short, Wingo offered a limited paradigm for assigning "additional duties" to federal magistrate judges by reference to their listed duties. Congress did not challenge this restrained approach to the Additional Duties Clause. Instead, two years after the Wingo decision, Congress amended the Magistrates Act "in order to clarify and further define the additional duties which may be assigned to a United States Magistrate in the discretion of a judge of the district court." 52 The updated version of $\S 636$ (b) no longer limited magistrate judges, as it had previously, to providing "assistance to a district judge in the conduct of pretrial or discovery proceedings in civil or criminal actions." $" 33$ Instead, the updated $\S 636(\mathrm{~b})$ explicitly allowed magistrate judges to "conduct evidentiary hearings, and to submit to a judge of the court proposed findings of fact and recommendations for the disposition," subject to "de novo determination" by a district judge, as part of magistrate judges'

\footnotetext{
47. Id. at $469-70$.

48. $I d$.

49. Id. at 470-71. There is no reason to suppose that the Judicial Conference's objection to broad language in the Additional Duties Clause was limited to habeas proceedings.

50. Id. at 474 (quoting Holliday v. Johnston, 313 U.S. 342, 352 (1941)).

51. Id. at 475-81 (Burger, C.J., dissenting). In reaching this conclusion, Chief Justice Burger's dissent attributed very little significance to the duties actually enumerated in $\S 636(\mathrm{~b})(3)$ because they were, in his view, "illustrative, not exclusive." Id. at 481.

52. United States v. Raddatz, 447 U.S. 667, 674 (1980) (quoting S. Rep. No. 94-625, at 1 (1976); H.R. Rep. No. 94-1609, at 2 (1976)).

53. 28 U.S.C. $§ 636(b)(2)(1968)$.
} 
enumerated powers. ${ }^{54}$ Congress continued to empower magistrate judges to "hear and determine any pretrial matter," with the exception of enumerated dispositive motions, such as motions to suppress evidence, subject only to review for clear error or legal error. ${ }^{55}$

In United States v. Raddatz, the Court confronted the question of whether, over a defendant's objection, a magistrate judge could conduct a suppression hearing and make dispositive credibility findings subject to de novo review of the cold record by a district judge. ${ }^{56}$ In contrast to Wingo, the Raddatz majority's inquiry was simple and straightforward because Congress's intent to allow magistrate judges to conduct pre-trial hearings subject only to district judge review of transcripts was "unmistakable." 57 The Raddatz majority also considered constitutional questions, evaluating the due process issue under the balancing test of Mathews v. Eldridge $e^{58}$ and concluding "that the due process rights claimed here are adequately protected by $\S 636(\mathrm{~b})(1) . "{ }^{, 59}$ The majority distinguished "the interests underlying a voluntariness [suppression] hearing" from the "criminal law objective of determining guilt or innocence." ${ }^{60}$ Finally, the majority held that de novo determination by a district judge avoided any "delegation" to a non-Article III judge and obviated the structural issue entirely, ${ }^{61}$ a conclusion at odds with the rationale of Wingo. ${ }^{62}$

Raddatz provoked four separate concurrences and dissents. ${ }^{63}$ For

\footnotetext{
54. 28 U.S.C. $\S 636(\mathrm{~b})(1)(\mathrm{B})(1976)$.

55. 28 U.S.C. $\S 636(\mathrm{~b})(1)(\mathrm{A})(1976)$.

56. 447 U.S. at $671-72$.

57. Id. at 676 . The Court contrasted the statutory language requiring "de novo determination" with the potential alternative "de novo hearing" that Congress might have used if it intended a district judge to rehear evidence. Further, the legislative history explicitly indicated that Congress did not intend a district judge to conduct a new hearing.

58. 424 U.S. 319 (1976).

59. United States v. Raddatz, 447 U.S. 667, 680 (1980).

60. Id. at 677-78. Peretz, in contrast, evaluated a matter related to trial, where guilt is determined.

61. Id. at $681-82$.

62. See Wingo v. Wedding, 418 U.S. 461 (1974). But see Mathews v. Weber, 423 U.S. 261, 270-71 (1976).

63. Justice Blackmun concurred because he found the due process issue to be even simpler than the majority: Because $\S 636$ simply adds a layer of procedural protection with "another neutral decisionmaker," it could never violate Due Process. 447 U.S. at 684-85 (Blackmun, J., concurring). Justice Powell agreed with the majority's interpretation of $\S 636(\mathrm{~b})(1)$, but he wrote separately because he felt that due process required a de novo hearing where a motion to suppress turned entirely on credibility. 447 U.S. at 686-87 (Powell, J., concurring and dissenting). Justice Stewart dissented based on the plain language of $\S 636(b)(1)$ and the "accepted meaning of de novo determination" (i.e., "an independent determination of a controversy that accords no deference to any prior resolution") which was uncontroverted, in his view, by the legislative history of the 1976
} 
purposes of understanding the issues presented in Peretz, Justice Marshall's Raddatz dissent warrants particular attention. Justice Marshall focused on the constitutional requirements of the Due Process Clause and Article III, arguing that the majority's approach of dividing a criminal trial itself from all other proceedings for purposes of due process undervalued a defendant's interest (and the public interest) in having other constitutional rights protected by suppression. ${ }^{64} \mathrm{He}$ also opined that Article III prohibited the delegation of any factual findings in a criminal case to an Article I officer, ${ }^{65}$ relying on decisions limiting military tribunals' jurisdiction over civilians, such as United States ex rel Toth v. Quarles. ${ }^{66}$ Finally, Justice Marshall agreed with the other dissenters that a "de novo determination" of credibility was not possible on a cold record, though Justice Marshall viewed the cursory (even illusory) review by a district judge as an Article III problem rather than a Due Process Clause problem subject to Mathews v. Eldridge balancing. ${ }^{67}$

In sum, the decisions in Wingo and Raddatz reflected recurring tensions that have continued to plague decisions regarding the authority of magistrate judges. The Wingo decision took a narrow view of the "additional duties" clause with a careful reading in light of specificallylisted duties, consistent with the text and legislative history of the Magistrates Act. Wingo also indicated that a delegation by Article III judges to Article I officers was potentially problematic even if, in theory, Article III judges might review the delegated decision. Although Raddatz recognized some value in de novo review by district judges, both Wingo and Raddatz made clear that Article III concerns lurked in the background and could serve to limit the role of Article I officers. Additionally, both the Wingo and Raddatz majorities recognized that proceedings determining criminal guilt or innocence constituted a distinct and significant stage different in kind from those regularly assigned to Article I officers.

\section{Article III Concerns and Article I Officers at Trials}

Two further legal developments set the stage for the federal courts to consider the use of magistrate judges at trials. First, through the Federal Magistrate Act of 1979, Congress authorized a magistrate judge to

\footnotetext{
amendments. 447 U.S. at 691-92 (Stewart, J., dissenting).

64. Id. at 700

65. Id. at 706 .

66. 350 U.S. 11 (1955).

67. Raddatz, 447 U.S. at $710-11$.
} 
conduct civil trials and enter judgment "upon consent of the parties," with an appeal taken directly from that judgment to the relevant federal court of appeals; ${ }^{68}$ to conduct misdemeanor trials with consent $;{ }^{69}$ and to preside over criminal post-trial matters, such as petitions for habeas corpus. $^{70}$ Second, the Supreme Court began using consent (previously a factor only in statutory analysis) as a factor in constitutional Article III analysis. $^{71}$ The latter development arose as the Court explored the legislative court doctrine and Article III structural limitations.

\section{The Legislative Court Doctrine}

The question of litigant consent as a part of Article III analysis arose in the bankruptcy context through the divided decision Northern Pipeline Construction Co. v. Marathon Pipe Line Co. ${ }^{72}$ Northern Pipeline Construction Co. brought state-law contract and tort claims as part of its reorganization in the Bankruptcy Court for the District of Minnesota. ${ }^{73}$ Marathon Pipe Line Co. objected on the basis of Article III. ${ }^{74}$

The four-justice Supreme Court plurality by Justice Brennan concluded that Article I bankruptcy judges, who lack salary protection and are appointed to fourteen-year terms, could not decide state-law claims consistent with Article III. ${ }^{75}$ Bankruptcy courts were not typical "legislative courts," such as territorial courts, courts-martial, and administrative courts for "public rights," because the delegation of statelaw claims to Article I adjudicators could not be accomplished under any "exceptional grant of power" to Congress. ${ }^{76}$ The plurality recognized that allowing Article I officers to decide all matters that might relate to a bankruptcy proceeding, in the interest of expediency, would wash away any Article III limitation and any requirement for a district judge. ${ }^{77}$ Finally, the plurality could not characterize bankruptcy judges as mere "adjuncts" of the district courts because the bankruptcy courts had all the

68. Federal Magistrate Act of 1979, Pub. L. No. 96-82, 93 Stat. 643 (codified as amended at 28 U.S.C. $\S 636(c)(2012))$.

69. Id.

70. Id.

71. See generally Hessick, supra 19 (focusing on Schor and Sharif in examining the weaknesses of consent as a basis for Article I adjudication).

72. 458 U.S. 50 (1982)

73. Id. at $56-57$.

74. Id.

75. Id. at 76 .

76. Id. at $64-69$.

77. Id. at $73-74$. 
"essential attributes" of Article III judicial power, including the power to preside over jury trials. ${ }^{78}$

A separate concurrence, authored by then-Justice Rehnquist and joined by Justice O'Connor, arguably controls in Northern Pipeline. ${ }^{79}$ In Justice Rehnquist's view, "so much of the Bankruptcy Act of 1978 as enables a Bankruptcy Court to entertain and decide Northern's lawsuit over Marathon's objection to be violative of Art. III." ${ }^{, 0}$ Justice Rehnquist relied on consent but as a means to narrow the holding, for consent was not a central factor animating in the constitutional analysis. ${ }^{81}$ Only Chief Justice Burger's dissent in Northern Pipeline ${ }^{82}$ understood consent to be among the important factors in Article III analysis, and some subsequent appellate decisions followed suit by incorporating consent into factor-balancing structural analysis. ${ }^{83}$

The Supreme Court further explored "legislative courts" just four years later in Commodity Futures Trading Commission v. Schor. ${ }^{84}$ The Court

78. Id. at $84-85$.

79. The relative precedential value of the Northern Pipeline opinions has always been somewhat uncertain. The Supreme Court majority in Stern, for example, drew heavily on the Northern Pipeline plurality without qualifying the decision based on Justice Rehnquist's concurrence. See Stern v. Marshall, 564 U.S. 462, 485-94 (2011). Meanwhile, the majority in Sharif referred to the Northern Pipeline plurality, concurrence, and a dissent. See Wellness Int'l Network, Ltd. v. Sharif, 135 S. Ct. 1932, 1946-47 (2015).

80. Northern Pipeline, 458 U.S. at 91 (Rehnquist, J., concurring).

81. Id. at 90 (Rehnquist, J., concurring). Justice Rehnquist expressed a desire to narrow the holding as much as possible to avoid contributing to the "arcane distinctions and confusing precedents" around Article III.

82. Id. at 92 (Burger, C.J., dissenting). Justice White also dissented, joined by Chief Justice Burger and Justice Powell, arguing for a simple balancing analysis weighing judicial independence against the need for the non-Article III forum. Id. at 106-12 (White, J., dissenting). Justice White's test emphasized the ability of district courts to review the record and, in so doing, created a blueprint for approving alienation of Article III power with limited Article III review. Id. at 100 (White, J., dissenting). Justice White recognized the inevitable end of his position: "There is no difference in principle between the work that Congress may assign to an Art. I court and that which the Constitution assigns to Art. III courts." Id. at 113 (White, J., dissenting). His position has never gathered a substantial following on the Court, and even the opinions favorable to delegation in bankruptcy cases have acknowledged that Article III constrains Congress's ability to assign matters to Article I adjudicators. Sharif, 135 S. Ct. at 1951 ("Although Congress may assign some bankruptcy proceedings to non-Article III courts, there are limits to that power."); see also Stern, 564 U.S. at 510-11 (Breyer, J., dissenting); but see Pacemaker Diagnostic, 725 F.2d 537, 542-45.

83. E.g., Pacemaker Diagnostic Clinic of Am., Inc. v. Instromedix, Inc., 725 F.2d 537, 541 (9th Cir. 1984) (en banc). The decisions in Collins v. Foreman, 729 F.2d 108 (2d Cir. 1984), and Wharton-Thomas v. United States, 721 F.2d 922 (3d Cir. 1983), mirrored Pacemaker Diagnostic. For example, Wharton-Thomas downplayed the Article III concerns in the civil context because a magistrate judge "is truly a part of the district court, appointed by its judges and subject to dismissal by them." 721 F.2d at 927.

84. 478 U.S. 833 (1986). Schor has been described as "[t]he closest that the modern Supreme Court has ever come to explaining Article III's internal distinction between structural and individual rights ...."See Stephen Vladeck, Deconstructing Hirota: Habeas Corpus, Citizenship, and Article 
concluded that the Commodity Exchange Act empowered the Commodity Futures Trading Commission ("CFTC") to decide state-law counterclaims in reparations proceedings. ${ }^{85}$ The majority addressed Article III concerns in two stages, separating a litigant's personal right to an Article III adjudicator from the general public's structural protection of judicial independence. On the former point, the majority concluded that Schor had waived his personal right to have the counterclaim heard in a district court. ${ }^{86}$ For the structural analysis, the majority used a factor-based approach, which carried over to the more-recent bankruptcy cases regarding Article III limitations. ${ }^{87}$ Although the Schor majority found no Article III violation for the CFTC, it is noteworthy that Schor's consent was not a factor in the structural analysis at all; consent mattered only for the personal right analysis. ${ }^{88}$ Justice Brennan dissented, joined by Justice Marshall, arguing for a strict reading of Article III with exceptions only for territorial courts, courts-martial, and public rights adjudications. $^{89}$

Northern Pipeline and Schor laid the groundwork for the Article III analysis that should have occurred in Peretz, for any confusion that might flow from the various opinions in Northern Pipeline was resolved by the seven-justice majority in Schor. Justice O'Connor's cogent Schor majority identified the limited relevance of litigant consent by dividing Article III protections into a personal right (waivable, such that consent matters) and a structural interest (unwaivable, such that consent does not matter). Although relying on various factors in the structural analysis, Schor omitted consent entirely, and Schor was the key Article III precedent at the time Peretz was decided. This logical and careful approach to considering consent in Article III analysis has been eroded by subsequent opinions - and Peretz was the first and most-damaging incursion.

\section{Magistrate Judge Jurisdiction over Civil Trials}

During the same decade as Northern Pipeline and Schor, many federal courts of appeals considered whether a magistrate judge could

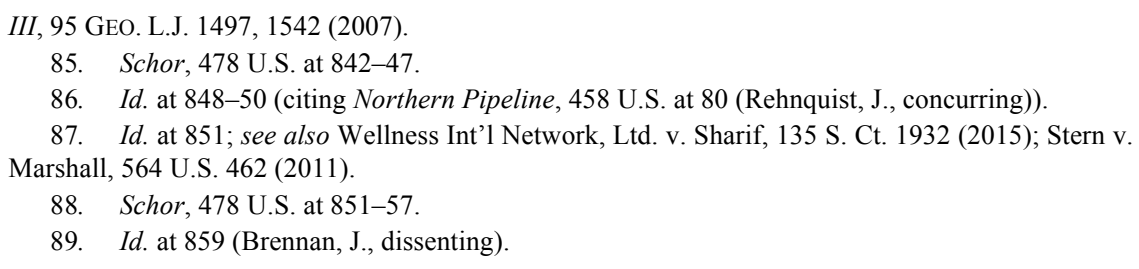


preside over a civil trial with the parties' consent without violating Article III, typically conducting a two-part inquiry looking at (1) the rights of the individual affected and (2) the structural effect on the independence of the judiciary. ${ }^{90}$ The Ninth Circuit's en banc decision in Pacemaker Diagnostic Clinic of America, Inc. v. Instromedix, Inc. is representative. ${ }^{91}$

When analyzing a civil litigant's "personal right to an Article III judge," the Pacemaker Diagnostic majority had little trouble accepting a waiver by civil litigants because even criminal defendants may waive other fundamental rights. ${ }^{92}$ But this approach reflects the danger of elevating consent to a dispositive element. Viewing the identity of the decisionmaker as a procedural issue, the Pacemaker Diagnostic majority compared waiver of an Article III judge to waiver of the lack of personal jurisdiction, deciding that it was unlike an unwaivable defect in subjectmatter jurisdiction. ${ }^{93}$ With respect to the individual right to an Article III judge, the Pacemaker Diagnostic majority was consistent with other decisions, but it did not conduct a separate Article III structural analysis independent of litigants' consent. ${ }^{94}$ In this respect, Schor is particularly instructive; as with subject-matter jurisdiction, structural concerns extend beyond the individual litigant's rights, so there must be some analysis of the power of the judicial officer to act. ${ }^{95}$

The Pacemaker Diagnostic dissent raised two important arguments that would later appear in other contexts. First, the consent (or lack thereof) by litigants was irrelevant, in the dissent's view, because Article

90. Pacemaker Diagnostic Clinic of Am., Inc. v. Instromedix, Inc., 725 F.2d 537, 540-41 (9th Cir. 1984).

91. See United States v. Bezold, 760 F.2d 999, 1001 (9th Cir. 1985) (collecting cases).

92. Pacemaker Diagnostic, 725 F.2d at 543

93. Id. Recall that the basis for personal jurisdiction is due process (and Federal Rule of Civil Procedure 4(k)), while the basis for subject-matter jurisdiction is actually Article III (and 28 U.S.C. $\S 1332$ ). See generally World-Wide Volkswagen Corp. v. Woodson, 444 U.S. 286, $293-94$ (1980); Verlinden B.V. v. Cent. Bank of Nigeria, 461 U.S. 480, 491-92 (1983). Magistrate judge jurisdiction raises structural concerns and, therefore, is more akin to subject-matter jurisdiction.

94. See Collins v. Foreman, 729 F.2d 108, 120 (2d. Cir. 1984) ("[T] section 636(c) provides a constraint against the wholesale delegation of judicial power to adjuncts of the district court. Thus, it helps ensure that the delegation will not reach a magnitude that would trigger Article III concerns.”).

95. The Pacemaker Diagnostic majority did not dwell on structural concerns that would still apply "despite waiver by affected parties" because district judges retained "extensive administrative control" and could resume jurisdiction "on [their] own initiative." 725 F.2d at 544. In the Ninth Circuit's view, litigants' ability to appeal also protected the judiciary from any improper influence of Congress in passing the Federal Magistrate Act. Id. at 545-46. This reasoning is circular. If the delegation in Pacemaker Diagnostic was an Article III violation, the deferential review by the Ninth Circuit (which, in any event, is not well-situated to review the factual nuances considered by a trial judge) left the harm uncured. 
III checks operate regardless of consent and because the burdened dockets that prompted the Federal Magistrates Act tend to coerce any waiver by a litigant. ${ }^{96}$ Second, the dissent framed the structural independence concern from the perspective of the particular presiding magistrate judge, not from the judiciary as a whole. This perspective appreciates that each magistrate judge serves in a less-secure post than an Article III judge. ${ }^{97}$

Specifically, magistrate judges serve eight-year terms (or just fouryear terms, if in a part-time capacity) rather than terms of life, must be reappointed upon turning seventy years old, and have their appointments and reappointments subject to review by a majority of district judges based on competence and the standards laid down by the Judicial Conference of the United States. ${ }^{98}$ They are subject to removal for cause ("incompetency, misconduct, neglect of duty, or physical or mental disability") or simply because their services "are no longer needed." 99 District judges' exercise of this power is protected by absolute judicial immunity, salary protection, and limited removal by Congress. ${ }^{100}$ Empirical research - at least with respect to civil matters - indicates that magistrate judges do behave somewhat differently than district judges. ${ }^{101}$ Specifically, in the civil contexts considered (a sampling of EEOC and civil cases from more than twenty districts), magistrate judges were seven percent more likely to produce defense verdicts in jury trials than district judges, but nine percent less likely to produce defense verdicts in bench trials. ${ }^{102}$ The same research also suggests that the ability of magistrate judges to write reports and recommendations that are accepted by district judges correlates with greater likelihood of being appointed as a life-tenured district judge. ${ }^{103}$ In short, the question of magistrate judges vs. district judges is not purely technical or theoretical: not respecting the balance demanded by $\S 636$ and Article III could affect case outcomes.

\section{Magistrate Judges' “Additional Duties” in Criminal Contexts}

The 1979 Act also authorized magistrate judges to try misdemeanor 
criminal cases with consent. Because the statute required consent for misdemeanors (in contrast to its silence regarding felonies), ${ }^{104}$ the defendant's consent was a given in appellate review of these cases, which focused on Article III. ${ }^{105}$ In United States v. Dobey, the Tenth Circuit weighed consent heavily because it had played a role in thenJustice Rehnquist's Northern Pipeline concurrence, though the circuit opinion pre-dating Schor did not differentiate individual Article III rights from structural concerns. ${ }^{106}$ As some circuit decisions considered consent entirely dispositive of the Article III challenge, misdemeanor defendants were often reduced to arguing that the consent was unknowing or involuntary. ${ }^{107}$

The expansion of magistrate judges' duties in the criminal context went beyond misdemeanor trials and habeas proceedings. Circuit splits arose as magistrates' "additional duties" pushed beyond pretrial matters in felony cases, such as the suppression hearing at issue in Raddatz, as far as felony voir dire. ${ }^{108}$ When considering felony voir dire, federal appellate courts attempted to reconcile Wingo, Raddatz, and other decisions into a standard approach to the Additional Duties Clause, diverging based on the different weight given to the importance of the duties actually listed in $\S 636$, the limitations imposed by Article III, and the effect of a defendant's consent. ${ }^{109}$

First, the statutory grant of authority to magistrate judges "to try persons accused of, and sentence persons convicted of, misdemeanors" appears to necessarily preclude felony trials by magistrate judges. ${ }^{110}$ Nevertheless, the Second and Ninth Circuits omitted any discussion of the listed duties in $\S 636$, treating voir dire as a pre-trial matter. ${ }^{111}$ The

104. 18 U.S.C. § 3401(b) (2012); see also 28 U.S.C. §636(a)(3) (2012) (cross-referencing $\S 3401)$

105. E.g., United States v. Byers, 730 F.2d 568, 570 (9th Cir. 1984).

106. 751 F.2d 1140, 1142 (10th Cir. 1985) (quoting Pacemaker Diagnostic Clinic of Am., Inc. v. Instromedix, Inc., 725 F.2d 537, 542-43 (9th Cir. 1984)).

107. 751 F.2d at 1143. Unsurprisingly, a panel of the Ninth Circuit reached the same conclusion, being bound by Pacemaker Diagnostic. See United States v. Byers, 730 F.2d 568, 570 (9th Cir. 1984) (per curiam).

108. Lewis v. United States, 146 U.S. 370, 374 (1892) ("[W]here the indictment is for a felony, the trial commences at least from the time the work of impaneling the jury begins.").

109. See, e.g., United States v. Ford, 824 F.2d 1430, 1432 (5th Cir. 1987) (en banc) (discussing strong objections of Judicial Conference of the United States to the notion of magistrate judges conducting felony trials).

110. 18 U.S.C. § 3401(a) (2012); see also 28 U.S.C. § 636(a)(3) (2012). See also, e.g., Marbury v. Madison, 5 U.S. 137, 174 (1803) ("Affirmative words are often, in their operation, negative of other objects than those affirmed; and in this case, a negative or exclusive sense must be given to them or they have no operation at all.").

111. See United States v. Bezold, 760 F.2d 999, 1001 (9th Cir. 1985) (beginning analysis with 
lack of emphasis on the listed duties can be traced to the position of Chief Justice Burger, though it is difficult to reconcile with the methodology of the Wingo majority, which focused on the listed duties because Congress had "carefully circumscribed" the role of magistrate judges. ${ }^{112}$

When a court focused on the listed duties, as the Wingo majority had, the analysis weighed against allowing magistrate judges to preside over felony voir dire. ${ }^{113}$ For example, a panel of the Eighth Circuit noted that, "Neither the timing nor the character of voir dire suggests its inclusion in the 'additional duties' provision." " Similarly, a majority of the en banc Fifth Circuit wove the whole tapestry together:

Throughout the debate [in earlier Supreme Court cases], there was no suggestions that the Act authorized magistrates to conduct the trial of other than petty offenses. The implicit assumption was that magistrates presiding over the trial of felonies was not envisioned, to a certainty - despite the presence of the additional duty language now said to allow magistrates to preside over jury selection in felony cases. ${ }^{115}$

Federal courts also differed noticeably regarding the potential encroachment on the judiciary's independence. The differences were most evident in the framing of a district judge's role in "reviewing" the already-selected jurors based on a transcript alone. Because felony trials remained the exclusive province of Article III judges, they undeniably retained some control over juries during the trial itself. ${ }^{116}$ Indeed, this simplification allowed several decisions to conclude that the role of

\footnotetext{
Additional Duties Clause and ignoring listed duties entirely); United States v. Garcia, 848 F.2d 1324, 1329 (2d Cir. 1988) ("[T]he legislative history states in so many words that Congress considered the 'additional duties' provision to be broad in scope and unrestricted by 'any other specific grant of authority to magistrates."'). While the Garcia circuit decision may be forgiven for the generic statement that the Additional Duties Clause is "broad," the lack of a citation is problematic, because Congress cautioned district judges to retain their "vital and traditional adjudicatory duties." United States v. Trice, 864 F.2d 1421, 1429 (8th Cir. 1988) (quoting 1976 U.S. Code Cong. \& Admin. News 6162,6172$)$ (emphasis in original).

112. Wingo v. Wedding, 418 U.S. 461, 470 (1974).

113. See Trice, 864 F.2d at 1426; Ford, 824 F.2d at 1435 .

114. Trice, 864 F.2d at 1428 .

115. Ford, 824 F.2d at 1432.

116. See Bezold, 760 F.2d at 1002 ("[T]he district judge had an opportunity for full de novo review of the qualifications of the jurors when the panel appeared before the judge for the start of trial. In addition the judge had wide discretion to disqualify jurors even after trial began.”).
} 
district judges in the felony trial itself kept judicial power firmly "within" the judicial branch. ${ }^{117}$ Other decisions hewed closer to Wingo, however, recognizing that the cold record of voir dire cannot, as a practical matter, be reviewed or supplemented effectively by the trial judge. ${ }^{118}$ Further, the alienation of Article III authority to a non-Article III actor raises structural concerns, even when district judges retain a theoretical supervisory power. ${ }^{119}$

Finally, the appellate cases of the 1980s divided over the importance of a defendant's consent, express or implied. Frequently, the defendant's consent proved an irresistible ground for affirming an apparently-fair conviction, with the Article III and statutory requirements both being treated like any other waivable trial right. ${ }^{120}$ Alternatively, recognizing the requirement for a district judge at felony voir dire necessarily affected the consideration of consent. For example, the Eighth Circuit held that a defendant could wait to object until he appeared before a district judge, reasoning that a magistrate judge had no power to be involved in felony voir dire at all, ${ }^{121}$ while the Ninth Circuit found only minimal Article III concerns and, accordingly, was willing to overlook a lack of consent entirely. ${ }^{122}$

The most insightful distinctions between felony voir dire and the pre-trial criminal context (such as the suppression hearing at issue in Raddatz) came from the en banc Fifth Circuit in United States v. Ford. First, in the view of the majority, the "one-shot" nature of felony voir dire distinguished it from other additional duties: "Unlike dispositive pretrial motions, there is no opportunity to convince the jury afresh at trial." " 23 Second, because jeopardy attaches upon the empaneling of the petit jury, it is very difficult to distinguish jury questioning and selection

117. See United States v. Garcia, 848 F.2d 1324, 1331 (2d Cir. 1988) ("[T]he delegation of authority here occurs entirely within the judicial branch, a circumstance which alleviates greatly the underlying structural separation of powers concern with one branch's encroaching upon the power of another.") (emphasis in original).

118. Ford, 824 F.2d at 1437 (noting that a second examination of a juror "would be a delicate exercise at best").

119. See id. at 1438 .

120. See, e.g., id. at 1438-39 (affirming where defendant did not object and "the trial was fundamentally fair"). Ford has another notable feature: The concurrence of Judge E. Grady Jolly would view all issues related to voir dire as arising under the Fifth and Sixth Amendments, setting aside Article III concerns, which makes his focus on a defendant's consent less unusual than relying on consent to overcome a structural defect. Id. at 1439-40 (Jolly, J., concurring).

121. United States v. Trice, 864 F.2d 1421, 1429 (8th Cir. 1988).

122. Bezold, 760 F.2d at $1001-02$.

123. Ford, 824 F.2d at 1437. 
from the felony trial itself. ${ }^{124}$ The Ford court affirmed on the somewhatunusual ground that the trial was nevertheless "fundamentally fair"-a harmlessness analysis that has never been reflected in Supreme Court's structural jurisprudence-but litigant consent alone could not cure the error. $^{125}$

In sum, the circuit decisions of the 1980s reflect a persisting divide in Article III jurisprudence. Many courts viewed the use of magistrate judges as a reasonable (perhaps, to borrow from Peretz, "indispensable") ${ }^{126}$ expedient presenting no serious danger because the Article I officers are conscientious and qualified. ${ }^{127}$ As the Eighth Circuit observed, however, "Since voir dire plays broader societal roles, we suspect that Congress did not intend to treat voir dire as simply preliminary," and it is too important to be a mere "additional duty." 28 The Supreme Court's first decision regarding felony voir dire adopted the Eighth Circuit's position.

\section{FELONY VOIR DIRE BEFORE THE SUPREME COURT}

Against this backdrop, the Supreme Court twice addressed felony voir dire. First, it considered a magistrate judge's authority when the defendant had not consented in Gomez v. United States. Second, the Supreme Court addressed the same question in light of the defendant's consent in Peretz v. United States.

\section{A. Felony Voir Dire Without Consent: Gomez v. United States}

The Supreme Court granted certiorari from the Second Circuit's decision in Garcia, ${ }^{129}$ and the justices faced a fully preserved challenge in Gomez v. United States: The petitioners objected to a magistrate judge presiding over voir dire both at the time of jury selection and at the start of trial before the district judge. ${ }^{130}$ Nevertheless, the petitioners made no

127. See, e.g., United States v. Garcia, 848 F.2d 1324, 1325 (2d. Cir. 1988) ("There is no doubt that everything has its season, and there is a time when an accused is entitled to the presence of a federal district court judge. But that season does not necessarily come with the commencement of the petit jury selection."). This article does not question the diligence of federal magistrate judges, but it recognizes that the distinction between magistrate judges and district judges matters. See Boyd, supra note 6 at $981-82$.

128. United States v. Trice, 864 F.2d 1421, 1427-29 (8th Cir. 1988).

129. Gomez v. United States, 488 U.S. 1003 (1989).

130. 490 U.S. 858,860 (1989).
} 
claim of prejudice, relying instead on the magistrate judge's lack of authority under $\S 636$ or, alternatively, under Article III and the Due Process Clause. ${ }^{131}$ The case produced a unanimous reversal, holding that felony voir dire was not one of the "additional duties" assignable to magistrate judges by statute.

The Gomez opinion adhered to the narrow view of the Additional Duties Clause established by Wingo. "When a statute creates an office to which it assigns specific duties, those duties outline the attributes of the office. Any additional duties performed pursuant to a general authorization in the statute reasonably should bear some relation to the specified duties." 132 The basic proposition inclusio unius exclusio alterius is unremarkable, ${ }^{133}$ but this statement in the unanimous Gomez opinion seemed to resolve a dispute over $\S 636(\mathrm{~b})(3)$ that dated back to Wingo. ${ }^{134}$

Gomez also drew a line between civil and misdemeanor trials, for which the Federal Magistrates Act provided express authority, and felony trials. ${ }^{135}$ This distinction informed the analysis of felony voir dire because, since the late nineteenth century, the Court had held that "the [felony] trial commences at least from the time when the work of empanelling the jury begins." 136 Gomez then emphasized the voir dire was the "primary means" for ensuring that the trier of fact would be "free from ethnic, racial, or political prejudice.",137

Having recognized the importance of voir dire, the Gomez opinion determined that it would be "incongruous" to assume that congressional silence allowed felony voir dire to be included as an "additional duty" under $\S 636(b)(3) .{ }^{138}$ The legislature's silence meant the statute provided no standard of review to be applied by a district judge: Would Congress consider jury selection a "dispositive" matter subject to de novo review, a "non-dispositive" matter subject to review only for clear error, or a unique stage of the proceeding subject to different rules entirely? ${ }^{139}$ The lack of any clear answer, and the practical difficulty of reviewing jury

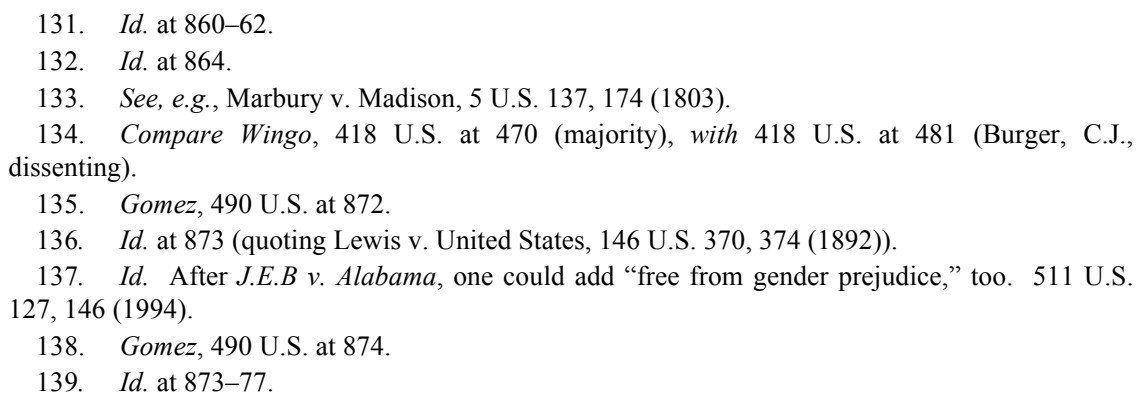


selection after the fact, led the Gomez decision to conclude that felony voir dire was better left to Article III judges. ${ }^{140}$

Finally, the Gomez opinion rejected any requirement that a defendant show prejudice. ${ }^{141}$ Gomez introduced an unfortunate ambiguity, however, which has haunted subsequent $\S 636$ jurisprudence. It described the nature of the right to an Article III judge as follows: "Equally basic [with the right to an impartial adjudicator] is a defendant's right to have all critical stages of a criminal trial conducted by a person with jurisdiction to preside." ${ }^{\text {"42 }}$ The failure to clearly bifurcate the right to an Article III judge at voir dire into a trial right (potentially waivable) and a structural concern (unwaivable) departed from the guidance of Schor and did not resolve whether a defendant's consent could be dispositive. Still, the Gomez decision was consistent with the logic of Wingo in its narrow interpretation of $\S 636(\mathrm{~b})(3)$, and the ambiguity regarding a defendant's consent could have been resolved by applying Northern Pipeline and Schor.

\section{B. Felony Voir Dire with Consent in the Courts of Appeals}

In the wake of Gomez, appellate judges divided over the significance of a defendant's consent. A panel of the Ninth Circuit reversed Darlina France's conviction even though she had not objected to a magistrate judge conducting voir dire. ${ }^{143}$ The unanimous France opinion focused on three pillars of Gomez: (1) that Congress's grant of authority in the Federal Magistrates Act "should be construed as an implicit withholding of the authority to preside at a felony trial"; ${ }^{144}$ (2) that jury selection is part of the criminal trial, and a critical part; ${ }^{145}$ and (3) that a district judge cannot meaningfully review voir dire because the presiding judge must scrutinize "gestures and attitudes of all participants to ensure the jury's impartiality," which is impossible from a cold transcript. ${ }^{146}$ The France decision concluded that magistrate judges lacked authority to conduct felony voir dire and the error "can never be treated as harmless." 147

In contrast, other circuits held that the requirement of an Article III

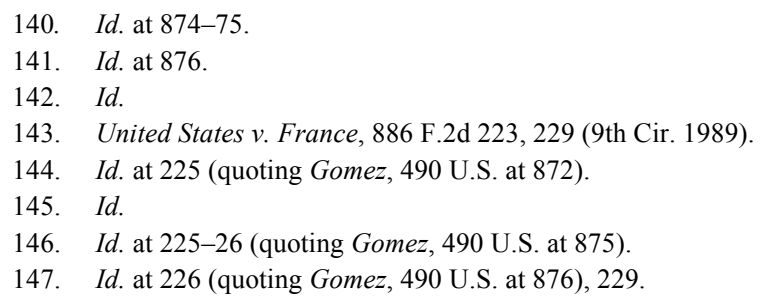


judge during felony voir dire was an individual trial right that could be waived, or even forfeited, by the defendant. ${ }^{148}$ When addressing the merits, these decisions focused on the defendant's right to a jury (plainly known to be waivable ${ }^{149}$ ), often without addressing the source of the magistrate judge's power or the structural concern about independence of the judiciary. ${ }^{150}$

This narrow framing of the issue, although widespread in appellate majorities following Gomez, provoked multiple circuit judges to write separately to highlight the structural issue. In his dissent from the First Circuit's decision in Lopez-Peña, Senior Judge Bailey Aldrich explained that, to the extent that a magistrate judge acts outside statutory authority, "he [is] a man off the street."151 Judge Mansmann's concurrence in Virgin Islands $v$. Williams ${ }^{152}$ expressed similar concerns, noting that, "Jury selection [is] not within the 'range of duties' that Congress intended magistrates to perform" and consent could not "confer jurisdiction where the Act withholds it."153 Finally, Judge Altimari dissented from the Second Circuit's decision in favor of the government in United States v. Mang Sun Wong because, despite the defendant's consent, the court should have "look[ed] no further than to the powers of the magistrate's office." 154 Together with the France panel, Judges Aldrich, Altimari, and Mansmann recognized that consent could not be dispositive without distorting the concerns animating Gomez.

148. "Whereas forfeiture is the failure to make the timely assertion of a right, waiver is the "intentional relinquishment or abandonment of a known right." ' United States v. Olano, 507 U.S. 725, 733 (1993) (quoting Johnson v. Zerbst, 304 U.S. 458, 464 (1938)). Most circuits agreed that Gomez applied retroactively, at least to the extent that it would reach criminal cases still on direct appeal. See, e.g., United States v. Lopez-Peña, 912 F.2d 1542, 1544-45 (1st Cir. 1989) (citing Griffith v. Kentucky, 479 U.S. 314, 328 (1987)).

149. See Fed. R. Crim. P. 23(a).

150. See United States v. Lake, 910 F.2d 414, 417 (7th Cir. 1990) ("Jury selection is no more critical than [other] constitutionally guaranteed rights."); Lopez-Peña, 912 F.2d at 1548 (discussing defendant's "right to have an Article III judge" without considering Article III structural concerns). But see United States v. Mang Sun Wong, 884 F.2d 1537, 1546 (2d Cir. 1989) (published order denying rehearing) (affirming conviction while acknowledging that "a magistrate's performance of [felony voir dire] is not authorized by the Federal Magistrates Act" without focusing on defendant's jury trial right).

151. 912 F.2d at 1552 (Aldrich, S.J., dissenting).

152. 892 F.2d 305, 312 (3d Cir. 1989). The Third Circuit panel majority held that "the Federal Magistrates Act permits a district court to delegate voir dire to a magistrate as an 'additional duty,' so long as the defendant expresses no objection." $I d$.

153. Id. at 312-13 (Mansmann, J., concurring) (quoting Gomez, 109 S. Ct. at 2242). Judge Mansmann concurred, rather than dissenting, because Williams had not shown plain error.

154. 884 F.2d at 1546 (Altimari, J., dissenting). 


\section{The Misstep in Peretz v. United States}

The Supreme Court revisited the issue of magistrate judge ${ }^{155}$ jurisdiction over felony voir dire in a case in which the defendants had consented: Peretz v. United States. ${ }^{156}$ In a 5-4 decision that provoked multiple dissents, the Court departed from several principles common to past Federal Magistrates Act and Article III cases (and reaffirmed just two years before in the unanimous Gomez opinion). The deviations in Peretz prove difficult to fully explain, particularly given that Justice Stevens authored Gomez, Peretz, and subsequently Nguyen (vacating Ninth Circuit opinions based on the presence of an Article IV judge, without statutory authority, despite having a quorum of two Article III judges ${ }^{157}$ ). The decisions are not persuasively reconcilable, and this article should be read with regard for its appreciation of the analyses in Gomez and Nguyen - and, therefore, its deep concern over the contrary reasoning in Peretz.

The Peretz majority began by reviewing the circuit split on the importance of a defendant's consent in the wake of Gomez, though it almost ignored the limited role of consent in Schor (relegated to a footnote). ${ }^{158}$ The majority skirted much of the rationale of Gomez by concluding that consent substantially changed the character of both the constitutional and statutory questions raised by having a non-Article III judge at felony voir dire. ${ }^{159}$ As part of its effort to cabin Gomez, the majority fell back on a trite point about the workload of federal trial courts: "Given the bloated dockets that district courts have now come to expect as ordinary, the role of the magistrate in today's federal judicial system is nothing less than indispensable." ${ }^{\prime 60}$ In a footnote, the Peretz majority pressed the point: "[T]he system created by the Federal

155. The Judicial Improvements Act of 1990 provided that a "magistrate" would "be known as a United States magistrate judge," but it made no substantive change to section 636. Pub. L. 101650 (Dec. 1, 1990). (For anyone inclined to view the title change as substantive, see Romeo and Juliet, Act II, Sc. 2, Lns. 43-51).

156. 501 U.S. 923 (1991). In fact, the Court had tried to address the question even sooner, on certiorari from the Ninth Circuit's decision in France, but the justices split 4-4. See United States v. France, 498 U.S. 335 (1991). The confirmation of Justice Souter allowed the Court to break the tie later in the October 1990 term. See Richard L. Berke, Senate Confirms Souter 90 to 9, As Supreme Court's 105th Justice, N.Y. TiMeS (Oct. 3, 1990), https://www.nytimes.com/1990/10/03/us/senateconfirms-souter-90-to-9-as-supreme-court-s-105th-justice.html [https://perma.cc/T84Q-M5ZT].

157. Nguyen v. United States, 539 U.S. 69, 82-83 (2003). See note 27, supra.

158. Peretz, 501 U.S. at 926-27 (quoting United States v. Musacchia, 900 F.2d 493, 502 (2d Cir. 1990)).

159. Id. at $927-28,932-33$.

160. Id. at 928 (quoting Virgin Islands v. Williams, 892 F.2d 305, 308 (3d Cir. 1989)). 
Magistrates Act has exceeded the highest expectations of the legislators who conceived it."161 That observation deserves particular reflection, for it acknowledges that district courts' delegation of certain work to nonArticle III adjudicators has been embraced by the judiciary itself to a greater extent than Congress intended. ${ }^{162}$

Continuing with the Federal Magistrates Act analysis, the Peretz majority ignored the many decisions emphasizing the importance of felony voir dire and concluded that "supervision of entire civil and misdemeanor trials" by a magistrate judge is "comparable in responsibility and importance to presiding over voir dire at a felony trial." 163 In doing so, the Court acknowledged that it was making a policy choice but was "confiden[t]" "that this reading of the additional duties clause strikes the balance Congress intended between the interests of the criminal defendant and the policies that undergird the Federal Magistrates Act." "164 This result has only weak support in the legislative history, as the majority referenced just one letter suggesting that a defendant's consent could affect a magistrate judge's power to preside. ${ }^{165}$

The Peretz majority then challenged the notion that structural constitutional protections are unwaivable because "litigants may waive their personal right to have an Article III judge preside over a civil trial" and "basic rights of criminal defendants are similarly subject to waiver."166 Nevertheless, the majority presented alternative analysis "assuming that a litigant may not waive structural protections provided by Article III." 167 Of course, there was no need to "assume" that Article III involved distinct personal right and structural components: Schor (and subsequent decisions, such as Stern) instruct that individual and structural protections are separate questions, and that consent is relevant

161. Id. at 928 n.5 (quoting Williams, 892 F.2d at 308).

162. Gomez counsels against this very line of thought animating Peretz when it states that Congress sets the specific duties for Article I officers. See Gomez v. United States, 490 U.S. 858, 864, 874-876 ("When a statute creates an office to which it assigns specific duties, those duties outline the attributes of the office."). The Peretz majority used the overall efficiency advantage of delegating work to magistrate judges to minimize the importance of the inquiry into the permissibility of delegation under the Federal Magistrates Act and Article III.

163. Peretz, 501 U.S. at 933. The court presents a similar gloss on the issue later when acknowledging that meaningful district judge review of jury selection would be "difficult" but concluding that magistrate judges have experience in observing witnesses and determining credibility. Id. at $936 \mathrm{n} .12$.

164. Id. at $933-34$.

165. Id. at 935 n.11.

166. Id. at 936.

167. Id. at 937. 
to the former but not the latter. ${ }^{168}$ The majority concluded that district judge supervision of a magistrate judge sufficed to overcome any structural issue, ${ }^{169}$ a conclusion at odds with the Peretz majority's earlier observation that district judge review of voir dire would be "difficult." 170

The Peretz dissents comprehensively countered the majority's reasoning. Justice Marshall, joined by Justices White and Blackmun, focused on Gomez, ${ }^{171}$ for the "reasoning in Gomez makes clear that the absence or presence of consent is entirely irrelevant to the Federal Magistrates Act's prohibition upon magistrate jury selection in a felony trial" and "the majority resolves the constitutional question in a manner entirely inconsistent with our controlling precedents." ${ }^{172}$ Justice Marshall defined the issue in Peretz as "jury selection in a felony trial," $" 173$ for voir dire represents the beginning of a felony trial under Lewis and sets up the "attachment of jeopardy" with the empaneling of the jury. ${ }^{174}$ This more-precise framing of the question produces a more compelling opinion than the majority.

Justice Marshall's dissent turned first to the Additional Duties Clause and notes that magistrate judge participation in felony trials undermines the very purpose of the Federal Magistrates Act, which was to increase "time available to [district] judges for the careful and unhurried performance of their vital and traditional adjudicatory duties"-duties that include felony trial and voir dire. ${ }^{175}$ After all, Congress expressly provided "a magistrate's limited authority to conduct misdemeanor and civil trials," thereby implicitly prohibiting supervision of felony trial, ${ }^{176}$ and Gomez had recognized that Congress understood voir dire to be part of a felony trial. ${ }^{177}$ Finally, Justice Marshall's dissent criticized the

\footnotetext{
168. Commodity Futures Trading Comm'n v. Schor, 478 U.S. 833, 851-57.

169. Peretz, 501 U.S. at 937.

170. Id. at 935 n.12 (citing Gomez, 490 U.S. at 873-76).

171. Id. at 941 (Marshall, J., dissenting). Justice Marshall's criticism of the majority for "interpretive gymnastics" was trendsetting, as similar analogies have appeared in many subsequent Supreme Court decisions. See Douglas Abrams, Sports in the Courts: The Role of Sports References in Judicial Opinions, 17 VILL. SPORTS \& ENT. L.J. 1, 15 (2010).

172. Id. at 941 (Marshall, J., dissenting).

173. Id. (emphasis added).

174. See Lewis v. United States, 146 U.S. 370, 374 (1892); see also, e.g., Gomez, 490 U.S. at

175. Peretz, 501 U.S. at 942 (Marshall, J., dissenting) (quoting H.R. Rep. No. 94-1609, p. 12 (1976)) (emphasis in original).

176. Id. at 943 (Marshall, J., dissenting).

177. Id. at 943 n.2 (citing Gomez, 490 U.S. at 873). Justice Marshall also reiterated that district judge review of voir dire is not meaningful and observed that the majority was requiring only oral consent by defense counsel, not written consent by the defendant himself, demonstrating striking insight by anticipating the question in Gonzalez v. United States, 553 U.S. 242 (2008). Id. at 944-48
} 873. 
majority for "creating authority for magistrates," 178 a criticism consistent with the later Nguyen decision. ${ }^{179}$

Turning to the constitutional question, Justice Marshall's dissent focused on the unwaivable structural concern: "Although parties may waive their personal guarantee of an independent Article III adjudicator, parties may not waive Article III's structural guarantee."180 If a magistrate judge's supervision of felony voir dire was allowed under the Federal Magistrates Act, Congress has attempted to exercise its Article I power to "impermissibly intrude on the province of the judiciary" and its Article III power. ${ }^{181}$ Justice Marshall explained that district judges cannot meaningfully review felony voir dire on a cold transcript, and the lack of meaningful review prevents delegation of Article III power under both Raddatz and Schor. ${ }^{182}$

Justice Scalia also dissented from the Peretz decision, though he wrote separately to build on Justice Marshall's criticisms by considering the judiciary's delegation of its own power. ${ }^{183}$ On the merits, Justice Scalia expressed "general agreement with Justice Marshall," "184 and asserted that the "canon of ejusdem generis [i.e., general wording accompanied by a list should be restrictively interpreted to things of the same type] keeps the 'additional duties' clause from swallowing up the rest of" the Federal Magistrates Act. ${ }^{185}$ The judiciary also may not "itself alienate its assigned powers," rebutting the majority's assertion that district judge supervision can cure any Article III concern regarding a magistrate judge's conduct of particular judicial functions. ${ }^{186}$ In short, even if the Additional Duties Clause allowed magistrate judge supervision of felony voir dire, Article III judges should not have accepted Congress's invitation to alienate their core judicial power.

\footnotetext{
(Marshall, J., dissenting).

178. Id. at 948.

179. See 539 U.S. $69,78-79$.

180. Peretz, 501 U.S. at 950 (Marshall, J., dissenting) (citations omitted) (emphasis in original).

181. Id. at 950; see also Commodity Futures Trading Comm'n v. Schor, 478 U.S. 833, 851-52

(1986). The Peretz majority's result is "particularly unfortunate" because "the most coherent reading of the Federal Magistrates Act," i.e., that magistrates may not conduct felony voir dire, "avoids [Article III] problems entirely." Peretz, 501 U.S. at 952 (Marshall, J., dissenting).

182. Id. at 951-52 \& n.7 (citing Raddatz, 447 U.S. at 683 (majority), 685 (Blackmun, J., concurring), and citing Schor, 478 U.S. at 853).

183. Peretz, 501 U.S. at $952-55$ (Scalia, J., dissenting). With typical thoroughness, Justice Scalia began with the question of forfeiture and concluded that the Court should overlook Peretz's failure to object because Gomez was decided after his conviction.

184. Id. at 955 (Scalia, J., dissenting).

185. Id. (citing Gomez v. United States, 490 U.S. 858, 872 (1989)).

186. Id. at 956 (emphasis in original).
} 


\section{Tracing the Threads Cut by Peretz}

The Peretz majority departed from several threads that had developed over the prior two decades. The listed duties in $\S 636 \mathrm{had}$ been critical guideposts for analysis of the Additional Duties Clause from the start in Wingo ${ }^{187}$ and again in Gomez. ${ }^{188}$ Although the Court had quoted some legislative history encouraging experimentation with magistrate judges in Mathews $v$. Weber, ${ }^{189}$ that case involved only preliminary review of an administrative record, which can be fully reviewed by a district judge from the same record later (unlike when a magistrate judge presides over live proceedings). ${ }^{190}$ Raddatz upheld magistrate judge jurisdiction over suppression hearings, yet that assignment was permitted by the express language of $\S 636(\mathrm{~b})(1)(\mathrm{A})$ with a standard of review (de novo determination, but not de novo hearing) also provided by $\S 636(\mathrm{~b})(1)(\mathrm{B}) .{ }^{191}$ The assignment of felony voir dire permitted in Peretz required substantial innovation by the judiciary itself. ${ }^{192}$ In addition to reading a consent requirement for felony voir dire into the Additional Duties Clause by questionable analogy to civil and misdemeanor trials (and creating a new question about who must give that consent ${ }^{193}$ ), the Supreme Court majority developed the standard of review out of whole $\operatorname{cloth}^{194}$ (de novo determination by a district judge, but only upon request of the parties). ${ }^{195}$ It also overlooked multiple indications that Congress viewed voir dire as part of trial (specifically, "its passage in 1975 of the Speedy Trial Act and its placement of rules pertaining to criminal petit juries in a chapter entitled

\footnotetext{
187. Wingo v. Wedding, 418 U.S. 461, 470 (1974).

188. Gomez, 490 U.S. at 864.

189. 423 U.S. 261, 267 (1976) (quoting Hearings on the Federal Magistrates Act Before Subcomm. No. 4 of the H. Comm. on the Judiciary, 90th Cong., 2d Sess., 81 (1968)) ("We hope and think that innovative, imaginative judges who want to clean up their caseload backlog will utilize the U.S. magistrates in these areas and perhaps even come up with new areas to increase the efficiency of their courts.").

190. Id. at 270 .

191. United States v. Raddatz, 447 U.S. 667, 675 (1980) (quoting H.R. Rep. No. 94-1609, at 3) ("The use of the words 'de novo determination' is not intended to require the judge to actually conduct a new hearing on contested issues.") (emphasis in original).

192. See Peretz v. United States, 501 U.S. 923, 935-37.

193. See Gonzalez v. United States, 553 U.S. 242, 249-51 (2008) (majority); id. at 266-67 (Thomas, J., dissenting).

194. Cf. Gomez v. United States, 490 U.S. 858 at 874 ("It is incongruous to assume that Congress implicitly required [de novo] review for jury selection yet failed even to mention that matter in the statute.").

195. Peretz, 501 U.S. at 939 (1991)
} 
'Trial." ",196).

The Article III analysis in Peretz was similarly out of step with the separation-of-powers cases of the 1980s. Indeed, the analysis of Peretz has been described as a Due Process Test (with balancing reminiscent of Matthews v. Eldridge ${ }^{197}$ ), which reflects Justice White's Northern Pipeline dissent rather than Justice Brennan's plurality or Justice Rehnquist's concurrence. ${ }^{198}$ The structural analysis in Peretz was also at odds with the Schor majority, which had resolved the ambiguity about the role of consent in the various Northern Pipeline opinions by considering consent only with respect to the individual's right to an Article III adjudicator, not the separate structural concern. ${ }^{199}$ Instead, Peretz used consent in its structural analysis in a way that made consent entirely dispositive, ${ }^{200}$ for Peretz could be read to allow Article III judges to alienate judicial power of any kind (with litigant consent) as long as they can theoretically claw the power back in other similar cases, though without meaningful review in any particular delegated case. ${ }^{201}$ This reality prompted Justice Scalia's admonition that "the Constitution guarantees not merely that no branch will be forced by one of the other branches to let someone else exercise its assigned powers - but that none of the branches will itself alienate its assigned powers."202 Finally, the Peretz majority failed to value voir dire as a significant moment in felony proceedings for both structural and practical purposes (despite acknowledging that voir dire is a "critical stage" of proceedings). ${ }^{203}$

In sum, the tenuous Peretz majority allowed pragmatism to override valid concerns that animated related Supreme Court precedent on the

\footnotetext{
196. Gomez, 490 U.S. at 873 (citations omitted).

197. 424 U.S. 319 (1976).

198. See Hinde, supra note 10 at 1171-73. In fact, Peretz arguably expanded on Justice White's position that "[t]here [is] no difference in principle between the work that Congress may assign to an Art. I court and that which the Constitution assigns to Art. III courts," Northern Pipeline Constr. Co. v. Marathon Pipe Line Co., 458 U.S. 50, 113 (White, J., dissenting), by allowing the Article III courts themselves to alienate power through an elastic interpretation of the Additional Duties Clause. See Hinde, supra note 10 at 1173.

199. See Commodity Futures Trading Comm'n v. Schor, 478 U.S. 883, 848-51 (1986) (citing Northern Pipeline, 458 U.S. at 80 n.31 (Rehnquist, J., concurring)).

200. See Huffman, supra note 28 at 1355.

201. See Hessick, supra note 19 at $730-31$.

202. Peretz v. United States, 501 U.S. 923, 956 (1991) (Scalia, J., dissenting) (emphasis in original).

203. Id. at 933; but see id. at 929 n.6 (noting that voir dire is a "critical stage" of a felony trial). Peretz should have recognized that voir dire was critical enough to demand an Article III adjudicator, which would have vindicated the importance of voir dire instead of paying it mere lip service. See, e.g., Lewis v. United States, 146 U.S. 370, 374 (1892); J.E.B. v. Alabama ex rel. T.B., 511 U.S. 127, 143-44 (1994).
} 
construction of $\S 636$, the structural protections in Article III, and the importance of voir dire. A review of post-Peretz cases reveals how the analysis in Peretz was a deviation from the overall arc of Article III jurisprudence rather than a meaningful course-correction.

\section{JUDICIAL POWER IN THE TWENTY-FIRST CENTURY}

Despite the deviations of the Peretz majority from other authoritative cases, commentators continue to rely heavily upon its analysis, ${ }^{204}$ especially as recent decisions regarding the power of bankruptcy judges (with and without litigants' consent ${ }^{205}$ ) have rekindled interest in the power of magistrate judges. Nevertheless, allowing magistrate judge jurisdiction over felony voir dire remains difficult to reconcile with contemporary cases on judicial power. Peretz is still an outlier with respect to interpretation of statutory grants of judicial power, the use of consent as a dispositive factor in Article III structural analysis, and the integrity of the felony criminal process.

\section{A. Statutory Authority of Non-Article III Judges: Nguyen v. United}

\section{States}

In Nguyen, the Supreme Court majority held that appellate panels of the Ninth Circuit consisting of two Article III judges and one Article IV judge lacked the authority to decide the appeals of federal criminal convictions at all. ${ }^{206}$ The statute at issue, 28 U.S.C. $\$ 292(a)$, allowed "the chief judge of a circuit to assign "one or more district judges within the circuit' to sit on the court of appeals."207 The Article IV judges who had participated sat on the District Courts of Guam and the Northern Mariana Islands (both within the Ninth Circuit), and the question was whether these Article IV judges qualified as "district judges" under the statute and, if not, whether the error required vacatur of the appellate opinions. ${ }^{208}$ Neither petitioner had objected to the composition of the panel nor even sought rehearing before the Ninth Circuit. ${ }^{209}$

The Nguyen majority by Justice Stevens (in an encore of Gomez

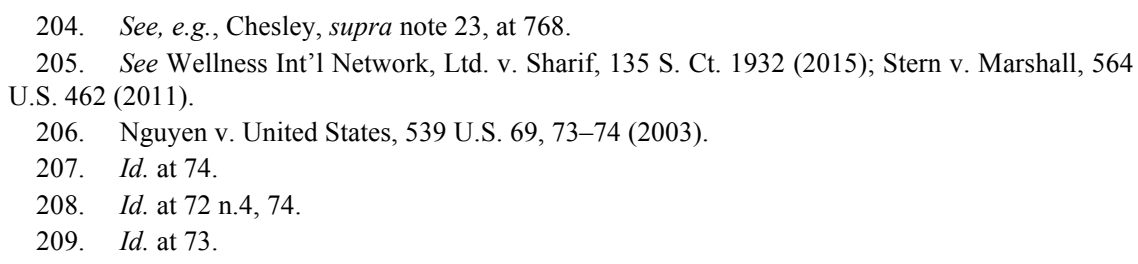


rather than Peretz) held that the designation of "district judges" under statute is restricted to Article III judges. ${ }^{210}$ The analysis involved a comprehensive review of the use of "district judges" in Title 28, and the majority noted that $\S 133$ (a) enumerates every judicial district and provides that "the President shall appoint, by and with the advice and consent of the Senate, district judges." 211 Despite the defendants' failure to object or demonstrate prejudice, ${ }^{212}$ the Nguyen majority drew a practical and useful line for when consent matters and when it does not: a judicial arrangement that is merely "irregular" requires analysis for prejudice, but one that is "impermissible" does not. ${ }^{213}$ As the use of Article IV judges was entirely impermissible under $\S 292(a)$, the majority reversed and remanded the case to the Ninth Circuit for hearing before a properly-constituted panel. ${ }^{214}$ Chief Justice Rehnquist's Nguyen dissent, joined by Justices Scalia, Ginsburg, and Breyer, would have instead applied plain error review, under which the failure to show prejudice would have been fatal. ${ }^{215}$

Nguyen reaffirmed the importance of Congress's grant of statutory authority to federal courts, especially with respect to the participation of non-Article III judges. The rigorous review of statutory context in Nguyen is consistent with the Supreme Court's approach to interpreting the Additional Duties Clause from Wingo and Gomez. ${ }^{216}$ On the other hand, Peretz ignored evidence that Congress did not intend a broad reading of the Additional Duties Clause, such as Congress's expressed intent that a federal magistrate judge would "assist the district judge to

210. Id. at 76 .

211. Id. at 74-75 (also quoting 28 U.S.C. § 134(a), providing that district judges hold office "during good behavior").

212. The Nguyen majority determined that the Ninth Circuit had "so far departed from the accepted and usual course of judicial proceedings as to call for an exercise of this Court's supervisory power." Id. at 74 (quoting Supreme Court Rule 10(a)). The majority focused on the statutory question and the "'historical significance' of the term 'United States District Court." Id. at 76 (quoting Mookini v. United States, 303 U.S. 201, 205 (1938)). The Nguyen majority explicitly declined to address any constitutional question, though the decision remains important in the context of magistrate judges' statutory power in felony proceedings, as subsequent appellate decisions have recognized. Id. at 76 n.9; see United States v. Harden, 758 F.3d 886 (7th Cir. 2014); Brown v. United States, 748 F.3d 1045 (11th Cir. 2014).

213. Nguyen, 539 U.S. at 79.

214. Id. at 83 .

215. Id. at 83-89 (Rehnquist, C.J., dissenting) (applying United States v. Olano, 507 U.S. 725 (1993)).

216. See Gomez v. United States, 490 U.S. 858, 872 (1989) (“[T]he carefully defined grant of authority [to magistrate judges] to conduct trial of civil matters and of minor criminal cases should be construed as an implicit withholding of the authority to preside at a felony trial."); Wingo v. Wedding, 418 U.S. 461, 471-73 (1974) (considering the importance of hearings, in particular, with a granular analysis in footnote 11). 
the end that the [Article III] judge could have more time to preside at the trial of cases." 217 Nguyen also counseled that, for violations that could never occur even with consent (i.e., those that are entirely impermissible), reversal should occur regardless of consent or demonstrable prejudice. $^{218}$ Finally, Nguyen reflected that any participation by even one improper judicial officer can undermine the entire proceeding, for the presence of a quorum of Article III judges on the Ninth Circuit panels failed to cure the error. ${ }^{219}$

The Peretz majority's conflict with Nguyen reflects the oddity of its statutory analysis. When decided, Peretz already conflicted with the reasoning in Gomez that, "Any additional duties performed pursuant to a general authorization in the statute reasonably should bear some relation to the specified duties."220 Gomez recognized that voir dire was comparable in importance to the presentation of evidence and arguments at felony trials. ${ }^{221}$ Congress itself indicated that the Federal Magistrates Act was intended to free district judges for availability at trial, ${ }^{222}$ which makes the use of magistrate judges in trial contexts, such as voir dire, puzzling. Finally, the Supreme Court in Batson observed that voir dire is not particularly burdensome for courts to supervise. ${ }^{223}$

In light of Nguyen, the proper statutory analysis of "additional duties" should begin with the listed duties and note the increased importance of felony matters compared with misdemeanor and civil trials. The analysis should review the listed duties as limiting principles, not simply examples for broad experimentation. Because involving magistrate judges in felony voir dire raises a difficult Article III inquiry - and, as the next section demonstrates, probably contravenes constitutional separation of powers - analysis of the Federal Magistrates Act should avoid the issue entirely unless Congress chooses to address felony voir dire explicitly (as it did for habeas proceedings following Wingo $^{224}$ ). In short, the result in Nguyen revealed that Peretz is based on diametrically-opposed premises: that voir dire is merely a preliminary "additional" duty yet burdensome enough that Article III judges need the

217. Peretz v. United States, 501 U.S. 923, 942 n.1 (1991) (Marshall, J., dissenting) (quoting S. Rep. No. 96-74 (1979) (regarding the amendments in the Federal Magistrate Act of 1979)).

218. Nguyen, 539 U.S. at 81.

219. Id. at 82 .

220. Gomez, 490 U.S. at 864.

221. Id. at 873 .

222. See S. Rep. No. 96-74, at 3 (1979).

223. Batson v. Kentucky, 476 U.S. 79, 99 (1986).

224. United States v. Raddatz, 447 U.S. 667, 674 (1980) (quoting S. Rep. No. 94-625, at 1 (1976); H.R. Rep. No. 94-1609, at 2 (1976)). 
option to share the work with Article I officers. Nguyen also reinvigorated the rationale of Wingo and Gomez by explaining that "Congress' decision to preserve the Article III character of the courts of appeals is more than a trivial concern . . . and is entitled to respect." 225

\section{B. Federal Bankruptcy Judge Jurisdiction: Stern v. Marshall and \\ Wellness International Network, Ltd. v. Sharif}

The Supreme Court thrust the issue of Article III limits on the authority of Article I judges into the legal spotlight in 2011 with its landmark decision in Stern v. Marshall. ${ }^{226}$ Four years later, the Court substantially limited the impact of Stern by again turning to consent as a factor in Article III analysis in Wellness International Network, Ltd. v. Sharif. ${ }^{227}$ Even with the evident differences in the Stern and Sharif majorities, neither redeems the reasoning and result in Peretz.

In Stern, a federal bankruptcy judge had adjudicated a state-law counterclaim for tortious interference in a bankruptcy proceeding because it would augment the bankruptcy estate. ${ }^{228}$ (Such state-law claims are often termed "Stern claims." 229 ) At issue was whether Article I bankruptcy judges possess the statutory and constitutional authority to adjudicate Stern claims and enter final judgments. ${ }^{230}$ The majority, written by Chief Justice Roberts, concluded that bankruptcy judges' statutory authority under 28 U.S.C. $\S 157$ extended to all claims arising under Title 11 and in a Title 11 case, including the state-law tortious interference counterclaim. $^{231}$ The majority closely scrutinized the language and structure of $\S 157$, noting that Congress "catalog[ued] 16 different types of proceedings that should receive "core' treatment" in $\S 157(b)(2)$, but Congress did not specify how to distinguish within that list between claims arising under Title 11 and claims that merely arise in a bankruptcy case. ${ }^{232}$ The Court further noted that describing a category of "core" proceedings that are merely "related to" a case would be oddly inconsistent, and "oxymoron is not a typical feature of congressional

\footnotetext{
225. Nguyen, 539 U.S. at 80 (citation omitted).

226. 564 U.S. 462 (2011).

227. 135 S. Ct. 1932 (2015).

228. Stern v. Marshall, 564 U.S. 462, 468-69 (2011).

229. Exec. Benefits Ins. Agency v. Arkison, 134 S. Ct. 2165, 2172 (2014).

230. Stern, 564 U.S. at 472-74.

231. Id. at 476. Federal bankruptcy judges are appointed for fourteen-year terms by the Court of Appeals for the Circuit in which the District Court is located. 28 U.S.C. § 152(a)(1) (2012); see Stern, 564 U.S. at 473.

232. Stern, 564 U.S. at 477.
} 
drafting.,"233 Nevertheless, the broad statutory designation of "core" proceedings created a constitutional issue. ${ }^{234}$

The Stern majority explained, "Article III could neither serve its purpose in the system of checks and balances nor preserve the integrity of judicial decisionmaking if the other branches of the Federal Government could confer the Government's 'judicial Power' on entities outside Article III." 235 The majority concluded that the amendments to the Bankruptcy Act of 1978 following the Northern Pipeline decision (in which the Court held that a bankruptcy judge could not enter final judgment on state common-law claims) did not resolve Article III concerns. ${ }^{236}$ "It is clear that the Bankruptcy Court in this case exercised the 'judicial Power of the United States' in purporting to resolve and enter final judgment on a state common law claim, just as the court did in Northern Pipeline." 237

The Stern majority touches on many issues, ${ }^{238}$ but three points are particularly relevant to this article. First, when interpreting Congressional delegations of judicial authority, the categories laid out by Congress are critical, and the majority carefully considered the entire structure of the relevant statute. ${ }^{239}$ Second, Congress cannot alienate judicial authority where the specific right or claim exists independent of the will of the federal legislature. ${ }^{240}$ Third, an Article I adjudicator is only an "adjunct" to the district courts (and, therefore, unable to offend Article III) if the decision is subject to full review by an Article III judge. $^{241}$ All these elements are absent when a magistrate judge presides over felony voir dire: section 636 excepts felony trial (of which voir dire

233. Id. (citing Northern Pipeline Constr. Co. v. Marathon Pipe Line Co., 458 U.S. 50, 71 (Brennan, J., plurality).

234. The Stern majority also addressed bankruptcy judge jurisdiction under $\S 157(b)(5)$, and its conclusion that the provision is not jurisdictional is straightforward in light of Arbaugh v. $Y \& H$ Corp., 546 U.S. 500 (2006). Stern, 564 U.S. at 479-80.

235. Stern, 564 U.S. at 484 . To emphasize the importance of separation of powers and Article III judges' life tenure, the majority quoted from The Federalist Papers and The Spirit of Laws. Id. at $482-84$.

236. Id. at $486-87$.

237. Id. at 487

238. Justice Scalia bemoaned the very complexity of the Stern decision in his concurrence: "something is seriously amiss with our jurisprudence in this area." Id. at 504-05 (Scalia, J., concurring).

239. Id. at $476-77$.

240. Id. at 493 ("The claim is instead one under state common law between two private parties. It does not depend on the will of [C]ongress; Congress has nothing to do with it.") (internal quotation marks omitted).

241. Id. at 500 (noting that bankruptcy judge's final judgment is subject to only appellate review by a district judge). 
is a component) from a magistrate judge's authority; the Constitution establishes jury trial rights, which are not subject to the will of Congress; and voir dire is not subject to meaningful review by a district judge from a cold transcript.

Justice Breyer's Stern dissent offered a different approach to Article III analysis, grounded more in the factor-based analysis of Schor than the formalism of Northern Pipeline, and his approach merits review before considering the subsequent Sharif decision and the effect of litigants' consent on bankruptcy judges' authority. The Stern dissent encouraged a "more pragmatic approach" that would find an Article III infirmity where "one branch of Government sought to aggrandize its own constitutionally delegated authority by encroaching upon a field of authority that the Constitution assigns exclusively to another branch." 242 For that inquiry, the dissent embraced several factors:

(1) the nature of the claim to be adjudicated, (2) the nature of the non-Article III tribunal, (3) the extent to which Article III courts exercise control over the proceeding, (4) the presence or absence of the parties' consent, and (5) the nature and importance of the legislative purpose served by the grant of adjudicatory authority to a tribunal with judges who lack Article III's tenure and compensation protections. ${ }^{243}$

The Supreme Court majority adopted a less-searching Article III structural analysis than in Stern when considering bankruptcy litigants' consent in Wellness International, Ltd. $v$. Sharif. ${ }^{244}$ Wellness International sought a declaratory judgment against Sharif, a debtor who filed bankruptcy under Chapter 7, to bring the assets of a living trust within the bankruptcy estate, and Sharif participated in the proceedings (apart from a pattern of non-compliance with discovery) until Stern was decided. ${ }^{245}$ The Seventh Circuit determined that the structural Article III problem posed by allowing a bankruptcy judge to preside could not be waived, so Sharif's failure to object was not fatal. ${ }^{246}$

The Supreme Court majority, written by Justice Sotomayor,

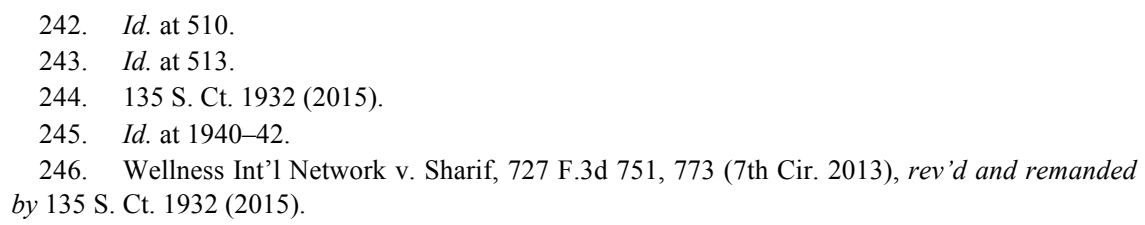


reversed. The Sharif majority began with the familiar refrain that "the number of magistrate and bankruptcy judgeships exceeds the number of circuit and district judgeships" and that, without Article I judges, "the work of the federal court system would grind nearly to a halt."247 After a short review of nineteenth-century arbitration cases, the majority reaffirmed the existence of two prongs of Article III analysis: a litigant's personal right to "an impartial and independent federal adjudication," which may be waived, and the structural interest in "checks and balances," which may not be waived. ${ }^{248}$ The Sharif majority then explained the importance of consent in Article III analysis because the right to a life-tenured adjudicator is a "personal right" subject to waiver "so long as Article III courts retain supervisory authority over the process," which obviates any structural concern. ${ }^{249}$

The Sharif majority reviewed the nature of bankruptcy courts to determine whether the district courts retain sufficient supervisory authority, including comparison to the supervision of magistrate judges as explained in Peretz. ${ }^{250}$ In short, bankruptcy judges are appointed and subject to removal by Article III judges, serve as integral parts of the district courts, and gain jurisdiction only by referral from the district courts. ${ }^{251}$ Drawing on Justice Breyer's Stern dissent, the majority also noted that bankruptcy judge jurisdiction is not an attempt by Congress "to aggrandize itself or humble the Judiciary." 252 Accordingly, the majority discerned no structural infirmity.

Chief Justice Roberts dissented in Sharif, joined in full by Justice Scalia and in part by Justice Thomas. ${ }^{253}$ As in the Stern majority, the Chief Justice's Sharif dissent recounted the American colonial experience of "intermingled legislative and judicial powers." 254 The dissent quickly returned to the Northern Pipeline plurality, noting that non-Article III adjudicators have general jurisdiction only in territories

247. Sharif, 135 S. Ct. at 1938-39.

248. Id. at 1943 (quoting Commodity Futures Trading Comm'n v. Schor, 478 U.S. 833, 848-51 (1986)).

249. Id. at $1943-44$.

250. Id. at 1945 (citing Peretz v. United States, 501 U.S. 923, 937(1991).

251. Id.

252. Id.; see also Stern v. Marshall, 564 U.S. 462, 510 (2011) (Breyer, J., dissenting).

253. Justice Alito concurred in the Sharif judgment, asserting that bankruptcy proceedings were analogous to the CFTC adjudications at issue in Schor. Sharif, 135 S. Ct. at 1949 (Alito, J., concurring). In a lengthy separate dissent, Justice Thomas explored the historical power of bankruptcy courts to demonstrate the impossibility of expanding the bounds of Article I bankruptcy power through litigants' consent. Id. at 1960-70 (Thomas, J., dissenting).

254. Id. at 1950 (Roberts, C.J., dissenting) (quoting Plaut v. Spendthrift Farm, Inc., 514 U.S. 211, 219 (1995)). 
(and the District of Columbia) and are otherwise confined to military tribunals, disputes over "public rights," and limited bankruptcy proceedings. ${ }^{255}$ To the extent a claim was a Stern claim, Congress could not assign adjudicatory power to an Article I officer and a litigant could not grant that power through a waiver. ${ }^{256}$ To emphasize the point, the dissent listed numerous cases involving the structural separation of other branches, such as NLRB v. Noel Canning and INS v. Chadha, which could not be cured by the consent of particular actors. ${ }^{257}$

The Chief Justice's Sharif dissent complained that the Sharif majority's result could only be reached through "an imaginative reconstruction of Stern."258 That criticism may inspire deja vu, for Justice Marshall bemoaned the contortions required of the Peretz majority to reach a result inconsistent with Gomez. ${ }^{259}$ Despite some similarities with Peretz, the Sharif decision does not (and could not) rehabilitate Peretz. As a threshold matter, Sharif can only assist with respect to Article III, for the delegation of Stern claims to bankruptcy judges is plainly permitted by $\S 157$, where the delegation of felony voir dire to magistrate judges as an "additional duty" is more doubtful. Even when focusing on Article III, however, the Stern claims at issue in Sharif remain meaningfully distinct from federal felony voir dire.

First, the Sharif majority built on Justice Breyer's Stern dissent, which had already concluded that a multi-factor analysis favored allowing delegation of Stern claims to bankruptcy judges. Federal felony voir dire is quite different from Stern claims, as reflected by application of Justice Breyer's five factors to the issue in Peretz. Only one factorthe defendant's consent to magistrate judge jurisdiction-favors the result in Peretz. The nature of the non-Article III tribunal does not weigh strongly in either direction: Magistrate judges are competent and qualified civil servants, but a recent statistical study suggests that magistrate judge outcomes are meaningfully different from district judge outcomes (at least in civil contexts). ${ }^{260}$ Justice Breyer's first three factors weigh strongly against the result in Peretz: (1) adjudication of a defendant's guilt or innocence to federal felony charges is as important

255. Id. at 1951 (citing Northern Pipeline Constr. Co. v. Marathon Pipe Line Co., 458 U.S. 50, 64-71 (1982) (Brennan, J., plurality)).

256. Id. at 1952-54 (Roberts, C.J., dissenting).

257. Id. at 1955 (citing, among others, NLRB v. Noel Canning, 134 S. Ct. 2550 (2014), and INS v. Chadha, 462 U.S. 919 (1983)).

258. Id. at 1957 (citing Stern v. Marshall, 564 U.S. 462, 514-18 (2011) (Breyer, J., dissenting)).

259. Peretz v. United States, 501 U.S. 923, 940-41 (1991) (Marshall, J., dissenting).

260. See Boyd, supra note 6, at 981-82. 
as a judicial function can be; (2) Article III judges exercise very little control over the proceeding because only limited review of voir dire is possible from a cold transcript; ${ }^{261}$ and (3) fair voir dire is critical, both to trial outcomes and "public respect for our criminal justice system," balanced against only limited administrative burdens. ${ }^{262}$

Second, federal felony proceedings are fundamentally different from state-law counterclaims in the bankruptcy context. A judge with life tenure and salary protections might never have decided Stern claims, because the state-law claims could have been brought in a state forum, where trial judges are often limited to terms of years and could even be subject to partisan elections. ${ }^{263}$ In contrast, a federal felony charge must be adjudicated in federal district court. Article III demands a district judge at federal felony trial and other critical stages (such as voir dire) because there is no alternate forum at which a judge lacking Article III protections might preside. ${ }^{264}$ In other words, short of the expansive reading of the Additional Duties Clause in Peretz, there would be no opportunity for an adjudicator without life tenure and salary protection to participate in the most significant aspects of federal felony proceedings.

Taken together, the Stern and Sharif majorities present a paradox, particularly through the contrary indications as to whether a narrow reading of Northern Pipeline or an expansive reading of Schor provides a better blueprint for Article III structural analysis. One need not resolve that tension, however, to recognize that the result in Peretz is dangerous. Through the lens of separation of powers or federalism, Stern claims are not nearly as significant as federal felony voir dire. Sharif could consign the state-law claims at issue to Article I bankruptcy judges without imperiling duties that should be exclusively reserved for Article III judges. To the extent that Sharif suggested results in the criminal context, those pronouncements are purely dicta. Rather than focusing narrowly on the pragmatism of Sharif and Peretz, courts should recognize the potential consequences of jurisdiction by consent, particularly in criminal cases. ${ }^{265}$ If litigant consent can override Article III structural protections in the federal felony context, in addition to waiving the litigant's personal right, then the structural prong of Article

\footnotetext{
261. See, e.g., Peretz, 501 U.S. at 935 n.12.

262. Batson v. Kentucky, 476 U.S. 79, 99 (1986).

263. See Judicial Selection in the States, BALLOTPEDIA, https://ballotpedia.org /Judicial_selection_in_the_states [https://perma.cc/72LM-QULY] (last visited Oct. 6, 2018).

264. See 28 U.S.C. $\S 636$ (2012); 18 U.S.C. $\$ 3401$ (2012).

265. See generally Hessick, supra note 19.
} 
III is a dead letter. ${ }^{266}$ Accordingly, Peretz remains an outlier by embracing a rule where litigants can waive all Article III protections, ${ }^{267}$ threatening to wash away all nuance reflected in the balancing of interests in Northern Pipeline, Schor, Stern, and even Sharif.

\section{Magistrate Judge Authority over Other Stages of Felony Proceedings}

A bedrock principle animating this article is that felony proceedings hold special significance beyond other trial court actions. Unfortunately, even this intuitive observation has been challenged based on the majority decisions in Sharif and Peretz. ${ }^{268}$ The Federal Magistrates Act itself draws a distinction by providing explicitly for magistrate judges' conduct of misdemeanor and civil trial with the litigant's consent, implicitly withholding authority over felony trials. ${ }^{269}$ The distinction is not the complexity of certain felony matters for the adjudicator, for the legal community has (justifiably) expressed almost-universal confidence in the competence of Article I judges. Rather, certain felony matters "are weighted with importance," 270 and those matters require an adjudicator with the constitutional protections and stature reserved for Article III judges. Several circuit courts have followed the lead of Peretz and read the Additional Duties Clause to include other significant felony matters - such as acceptance of guilty pleas - but only with litigants' consent. $^{271}$ Although only a minority, two courts of appeals have woven together instructive decisions regarding statutory grants of authority and structural protections and recognized limits on the power of litigant consent.

In Brown v. United States, the Eleventh Circuit delved into the nature of collateral attacks on federal criminal convictions and determined that "a $\S 2255$ proceeding is not a 'civil matter' for purposes of $\S 636(\mathrm{c}) ., 272$ Brown concluded that Congress did not intend $\S 636(\mathrm{c})$ to empower

\footnotetext{
266. See Wellness Int'1 Network, Ltd. v. Sharif, 135 S. Ct. 1932, 1958 (2015) (Roberts, C.J., dissenting) (citing Commodity Futures Trading Comm'n v. Schor, 478 U.S. 833, 851 (1986)).

267. See Gomez v. United States, 490 U.S. 858, 873 (1989).

268. See Chesley, supra note 23, at 771.

269. See Gomez, 490 U.S. at 871-72.

270. United States v. Harden, 758 F.3d 886, 889 (7th Cir. 2014).

271. See, e.g., United States v. Benton, 523 F.3d 424, 431-32 (4th Cir. 2008); United States v. Woodard, 387 F.3d 1329, 1332-33 (11th Cir. 2004); United States v. Ciapponi, 77 F.3d 1247, 1250 52 (10th Cir. 1996).

272. Brown v. United States, 748 F.3d 1045, 1047 (11th Cir. 2014). Wingo v. Wedding, 418 U.S. 461 (1974), and the 1976 amendment to the Federal Magistrates Act, Act of Oct. 21, 1976, Pub. L. No. $94-577,90$ Stat. 2729 , dealt with $\S 2241$ proceedings, which review state convictions.
} 
magistrate judges to enter final judgments on $\S 2255$ motions because it would entrust final review of a district judge's trial supervision to a magistrate judge. ${ }^{273}$ Thus, Brown necessarily concluded that a district judge must preside over a felony trial. Brown also noted that magistrate judge jurisdiction may not be conferred by litigants' consent where there is a structural Article III concern, consistent with Schor and Stern but not Peretz. ${ }^{274}$

The Seventh Circuit expressed similar concerns in United States $v$. Harden. Local Rule 72.1(b) of the United States District Court for the Southern District of Illinois provided that "[w]ith the consent of the parties, a magistrate judge is authorized to: (1) conduct voir dire and select petit juries for the District Court; (2) accept guilty pleas in felony cases, order presentence investigation reports, and file reports and recommendations with the District Court." 275 The court determined that magistrate judges could not accept guilty pleas-only file reports and recommendations for district judges' review-because " $[t]$ he task of accepting a guilty plea is a task too important to be considered a mere 'additional duty" under $\S 636 .{ }^{276}$ The Harden decision focused on the statutory question (and did not need to reach the Article III issue, as it found felony guilty pleas outside the Additional Duties Clause), but the court observed the now-familiar rule that consent alone cannot be dispositive. ${ }^{277}$ Finally, Harden explained the break with other circuitswhich have held, based on the usual efficiency concerns, that magistrate judges may accept guilty pleas ${ }^{278}$ - by returning to the fundamental significance of felony conviction: "A felony guilty plea is equal in importance to a felony trial leading to a verdict of guilty."279

Notably, Brown and Harden predate Sharif, with its emphasis on litigants' consent. Still, Sharif involved only state-law civil claims, so the concerns in Brown and Harden regarding significant stages of felony trial proceedings remain valid. These appellate decisions focused on the

273. Brown, 748 F.3d at $1065-67$.

274. Id. at 1069-70 (quoting both Stern v. Marshall, 131 S. Ct. 2594, 2608 (2011) and Commodity Futures Trading Comm'n v. Schor, 106 S. Ct. 3245, 3255 (1986)). Much like Gomez, the narrow interpretation of $\S 636$ (c) in Brown was also motivated by constitutional avoidance. See Brown, 748 F.3d at 1070-71.

275. Harden, 758 F.3d at 887 . Note that Local Rule 72.1 equated felony voir dire and felony guilty pleas. The Seventh Circuit's holding that magistrate judges may not accept the latter should give one pause about whether, as a matter of logic (rather than adherence to Peretz), magistrate judges may preside over the former.

276. Id. at 888 .

277. Id. at $889-90$.

278. Id. at 891 .

279. Id. 
significance of a task, rather than its technical complexity for an adjudicator, preserving limits on the delegation of felony duties to magistrate judges.

The contrary position - that the supervision of magistrate judges by district judges alleviates all constitutional concerns and enables essentially any delegation-ignores the realistic danger that appointed Article I officers will garner an ever-increasing percentage of federal trial duties, to the detriment of the life-tenured Article III judges the framers intended. Many simply observe that magistrate judges are "indispensable." This equanimity, sometimes even eagerness, for greater magistrate judge participation may reflect the belief that life tenure for federal judges is unimportant (or even be harmful to judicial work product). ${ }^{280}$ In this vein, a number of federal courts of appeals have embraced broad magistrate judge authority as a matter of efficiency. ${ }^{281}$ But the requirements of life tenure and salary protection enshrined in Article III by the Framers retain value in our constitutional system, as even trial judges are subjected to populist pressure in the digital age. ${ }^{282}$

Empirical data reflects a longstanding trend toward increased magistrate judge usage without a corresponding increase in district judgeships. The notion that delegations by district judges to magistrate judges are purely voluntary (and that litigant consent is similarly voluntary) overlooks the lack of new Article III judgeships, forcing district judges to share more and more of their caseloads. ${ }^{283}$ From 1990 to 2014 the number of pretrial and "additional" felony matters referred to magistrate judges annually increased over 400 percent, from 35,576 per year to 182,230 per year. ${ }^{284}$ Peretz paved the way for the ever-increasing workload of magistrate judges, of which criminal matters (when including collateral attacks) comprise a greater portion than even civil matters or administrative appeals. ${ }^{285}$ Reevaluation is overdue. Can Congress simply freeze the number of district judgeships - and leave

280. See, e.g., Term Limits, FIX THE COURT, https://fixthecourt.com/fix/term-limits/ [https://perma.cc/CZL4-H2W9] (last visited Oct. 6, 2018).

281. See generally Harden, 758 F.3d at 891 (collecting cases).

282. See, e.g., Veronica Rocha, Judge in Stanford Swimmer Sexual Assault Case Faces Recall Campaign, L.A. Times (June 26, 2017), http://beta.latimes.com/local/lanow/la-me-ln-judge-perskyrecall-election-effort-20170626-htmlstory.html [https://perma.cc/ZKR7-TK2T]; see generally Dan McLaughlin, The Threat to the Integrity of an Independent Judiciary, NATIONAL REVIEW (Feb. 9, 2017), http://www.nationalreview.com/article/444761/courts-abuse-power-ignore-law-since-franklin -roosevelt [https://perma.cc/8USY-7KJ6].

283. Mendel, supra note 23, at 1809.

284. Lee \& Davis, supra note 8, at 936; id. at 938 (stating that during that period, felony defendant filings increased just 22 percent).

285. See id. at 945 . 
numerous district judgeships vacant-indefinitely, allowing larger and larger caseloads to force the federal judicial workload onto the shoulders of Article I officers? If another quarter century passes with a 400 percent increase in magistrate judge felony workloads, the federal criminal process could be reduced further from "a system of pleas, not a system of trials" ${ }^{286}$ to a system of pleas and trials before Article I officers that, as a constitutional matter, belong to the same branch of government that defined the offenses. ${ }^{287}$

Accordingly, the observation in Sharif that, "Adjudication based on litigant consent has been a consistent feature of the federal court system since its inception," 288 does not address the larger concerns at issue. Congress almost certainly did not intend to allow delegation of all judicial tasks to magistrate judges, which would render the statutory listing of duties entirely superfluous. ${ }^{289}$ And if that were Congress's intent, the law would represent the kind of encroachment on judicial independence that offends separation of powers. ${ }^{290}$ Finally, as the Supreme Court has noted the importance of voir dire to trial ${ }^{291}$ and observed that it is not particularly burdensome for courts to supervise, ${ }^{292}$ it is difficult to understand why it is necessary for district judges to delegate that task when, in any event, a district judge must supervise the trial itself. Even when compared with rulings after the presentation of evidence begins, felony voir dire arguably constitutes the most critical moment in any Article III case, for it implicates (1) the rights of the accused, (2) each prospective juror's right to trial participation free of racial or gender prejudice, and (3) the integrity of the chosen petit jurors.

\section{CONCLUSION}

One of the ambiguities created by the expansive reading of $\S 636(b)(3)$ in Peretz-specifically, whether the defendant must personally consent to magistrate judge jurisdiction over felony voir

\footnotetext{
286. Lafler v. Cooper, 566 U.S. 156, 158 (2012).

287. See generally Wellness Int'1 Network, Ltd. v. Sharif, 135 S. Ct. 1932, 1954 (2015) (Roberts, C.J., dissenting).

288. Sharif, 135 S. Ct. at 1947.

289. Gomez v. United States, 490 U.S. 858, 864 (1989) ("Any additional duties performed pursuant to a general authorization in the statute reasonably should bear some relation to the specified duties.").

290. See, e.g., Sharif, 135 S. Ct. at 1947 (quoting Commodity Futures Trading Comm'n v. Schor, 478 U.S. 833, 855 (1986) (Brennan, J., dissenting)).

291. J.E.B. v. Alabama ex rel. T.B., 511 U.S. 127, 134-40; 511 U.S. at 147 (O'Connor, J., concurring); Batson v. Kentucky, 478 U.S. 79, $98-99$ (1986).

292. Batson, 478 U.S. at 99.
} 
dire-reached the Supreme Court in Gonzalez v. United States. ${ }^{293}$ The Court held that defense counsel's consent sufficed and accepted the holding in Peretz without reexamining its validity. ${ }^{294}$

As the lone dissenter, Justice Thomas would have taken a broader view and revisited Peretz itself. He would have held "that the delegation of voir dire in this [felony] case was statutory error." ${ }^{295}$ Reprising some points raised by Justice Marshall in his Peretz dissent, Justice Thomas argued that Gomez offered a more persuasive reading of the Additional Duties Clause than the Peretz majority's "revisionist construction." 296 Justice Thomas also noted that the Gonzalez case arose due to the distortion of the Additional Duties Clause beyond Congress's intent, for Congress would otherwise have indicated whether a defendant's written consent-as opposed to counsel's consent, or some other form-was necessary if magistrate judge authority over felony voir dire had been intended. ${ }^{297} \mathrm{He}$ also observed that, under Nguyen, judicial acts that were completely beyond statutory authority were subject to review despite the lack of a timely objection. ${ }^{298}$ Justice Thomas also briefly addressed the shortcomings of the constitutional analysis in Peretz, noting the term of office and removal provisions in 28 U.S.C. $\S 631$ and observing that, "[W]hatever their virtues, magistrate judges are no substitute for Article III judges in the eyes of the Constitution." 299

The scenario presented in Peretz and Gonzalez will never provide compelling facts: A defendant who consents to participation by a qualified magistrate judge is not a sympathetic litigant when complaining that, despite crowded dockets, a life-tenured district judge should have insisted upon supervising voir dire. Yet the structural protections of the Constitution sometimes demand inefficient results, for the concern is not

\footnotetext{
293. 553 U.S. 242 (2008).

294. Id. at 251. Justice Marshall had anticipated this result in his Peretz dissent. See Peretz v. United States, 501 U.S. at 947 n.6 (Marshall, J., dissenting). Justice Scalia concurred, disagreeing with the "tactical-vs.-fundamental test" the Gonzalez majority used to determine whether a defendant's personal consent was necessary as lacking a basis in the Constitution. Gonzalez, 553 U.S. at 254-57 (Scalia, J., concurring). He would instead have held that "all waivable rights (except, of course, the right to counsel) can be waived by counsel." Id. at 257. Justice Scalia did not engage with the underlying rationale of Peretz, with which he had disagreed in 1991. Id. at 254-58.

295. See Gonzalez, 553 U.S. at 258 (Thomas, J., dissenting).

296. Id. at 261 (quoting Peretz, 501 U.S. at 947 (Marshall, J., dissenting)).

297. Id. at 262; see also Peretz, 501 U.S. at 947 n.6 (Marshall, J., dissenting). Recall that Congress specifically required a defendant's express, informed consent before a magistrate judge could preside over a misdemeanor trial. Gonzalez, 533 U.S. at 262 (Thomas, J., dissenting).

298. Gonzalez, 533 U.S. at 270.

299. Id. at 268 .
} 
the fairness of any particular trial; ${ }^{300}$ it is the fairness of our entire system.

Congress cannot designate felonies and punishments then consign adjudications to a system of Article I officers - even with the complicity of the federal judiciary itself-whose members do not enjoy the same independence as their Article III colleagues. Congress likely did not intend to do so, for felony voir dire is too significant to be termed a mere "additional duty" under the Federal Magistrates Act. The data available on civil matters indicates that magistrate judges and district judges are not fungible based on outcomes, ${ }^{301}$ yet magistrate judges garner an everincreasing workload in felony matters. ${ }^{302}$ Statistics and statutes aside, if Article III itself imposes some limitation on which officer may preside over federal cases, ${ }^{303}$ it must draw a line at felony trials - and that line ought to encompass the significant duty of overseeing felony voir dire.

The legal community should continue to acknowledge the value of Article I judges without encouraging the trend that could eventually make life-tenured federal judges a novelty rather than a norm. ${ }^{304}$ First, commentators should recognize Peretz as just one piece of the puzzleand a black sheep at that. Arguments to expand magistrate judge jurisdiction to new frontiers, such as felony guilty pleas and collateral review, must be cognizant of the countervailing concerns expressed in Wingo, Gomez, Schor, Stern, and other cases. Second, federal courts themselves should exercise caution when delegating felony duties and reviewing those delegated duties on appeal. ${ }^{305}$ The demands of efficiency should not sweep away the few inviolable Article III duties that remain. Finally, when an opportunity arises, the Supreme Court itself should consider whether Peretz remains good law despite its deviations from more recent decisions (such as Nguyen and Stern) that reflect the persuasive reasoning of pre-Peretz jurisprudence (such as Schor and Gomez).

\footnotetext{
300. See generally Weaver v. Massachusetts, 137 S. Ct. 1899, 1910 (2017).

301. See Boyd, supra note 6, at 981-82.

302. See Lee \& Davis, supra note 8, at 936-38.

303. See, e.g., Commodity Trading Comm'n v. Schor, 478 U.S. 833 (1986); Stern v. Marshall, 564 U.S. 462 (2011).

304. "As experience demonstrates, expediency will inevitably support more Article I adjudications as the volume of litigation increases ...." Hessick, supra note 19, at 757 . The Supreme Court missed an opportunity to correct this trend in Wellness Int'l Network v. Sharif, $135 \mathrm{~S}$. Ct. 1932, 1938-39 (2015), observing that "the number of magistrate and bankruptcy judgeships exceeds the number of circuit and district judgeships" while rendering a decision that encouraged ever-greater use of Article I officers.

305. See Nguyen v. United States, 539 U.S. 69, $73-74$ (2003).
} 
With the expanding role of magistrate judges over the last quartercentury, particularly in felony matters, the narrow majority decision in Peretz $v$. United States remains as dangerous as ever. ${ }^{306}$ Peretz continues to animate legal thought on magistrate judges' duties despite contravening other decisions on statutory construction, constitutional limitations, and the importance of certain court proceedings derived from the inherent dignity of litigants and criminal adjudication. ${ }^{307}$ Any application of Peretz should, at a minimum, be tempered by careful review of other precedent.

306. See Huffman, supra note 28, at 1361.

307. See, e.g., Stern, 564 U.S. at 493; Nguyen, 539 U.S. at 73-74. 